\title{
In vitro \& In vivo Phytochemical Evaluation of Bioactive Components Against Hyperglycemic-induced Oxidative Stress in Streptozocin Rat Model: A histopathological investigation
}

\author{
Arif Nazir $^{1, *(\mathbb{D})}$, Rahat Mustafa ${ }^{1 \mathbb{D}}$, Munawar Iqbal ${ }^{1(\mathbb{D}}$ \\ 1 Department of Chemistry, The University of Lahore, Lahore; anmalik77@gmail.com (A.N.); profrahat@gmail.com \\ (R.M.); bosalvee@yahoo.com (M.I.); \\ * Correspondence: anmalik77@gmail.com (A.N.);
}

Scopus Author ID 36996122200

Received: 30.09.2021; Revised: 1.11.2021; Accepted: 4.11.2021; Published: 24.11.2021

\begin{abstract}
The in vitro antidiabetic and antioxidant potential of Punica granatum, Eriobotrya japonica, and Musa acuminata leaves were evaluated using normal and streptozocin (STZ) induced diabetic rats. Experimental diabetes was induced into Wister rats using streptozocin $(40 \mathrm{mg} / \mathrm{kg})$, injected intraperitoneal (IP). Orally crude methanolic leaves extracts were administered in streptozocin induced diabetic rats $(\mathrm{n}=6)$ along with the fractions (chloroform, ethyl acetate, and aqueous) of $P$. granatum, $E$. japonica, and M. acuminata $(50 \mathrm{mg} / \mathrm{kg}$ ) along with standard drug glimepiride $(2 \mathrm{mg} / \mathrm{kg}$ ) for 28 days. Rats' blood samples were tested for blood glucose using glucose oxidase reactive strips and glucometer. Glucose was administered to nondiabetic control rats. The rats were also treated with glimepiride and leaves extracts of $P$. granatum, E. japonica, and $M$. acuminata to check the oral glucose tolerance (OGTT). Blood glucose levels were checked at 0, 30, 60, 120 minutes intervals after drug administration. The effect of various fractions of leaf extracts on the bodyweight of rats was also studied. Data obtained was evaluated by two-way Analysis of Variance (ANOVA) and expressed as standard deviation. Leaves extracts exhibit significant antidiabetic and antioxidant properties. These medicinal plants with antioxidant and antidiabetic properties could be an economical source of local medicine for diabetes.
\end{abstract}

Keywords: analytical assay; antidiabetic; antioxidant; phytochemicals; streptozocin; histopathology (C) 2021 by the authors. This article is an open-access article distributed under the terms and conditions of the Creative Commons Attribution (CC BY) license (https://creativecommons.org/licenses/by/4.0/).

\section{Introduction}

Herbal medicine is a natural medicinal source that uses herbs and plant extracts for curing various human disorders. Herbal medicine has become a usual practice with the advancement in chemicals using herbal products in the prevention and treatment, along with the improvement in analysis and quality control [1-6]. World health organization (WHO) reported that 119 different plant part extracts are being utilized to manage animal diseases [79]. Plant-derived substances remain the basis of most commercial medicines currently used to treat pain, heart diseases, asthma, high blood pressure, and other health problems $[10,11]$. The curative abilities of medicinal plants are known at a global level. It is believed that out of 8,000 medicinal herbs 1000 are present in Pakistan [12-15].

Diabetes is a common disease caused by carbohydrate metabolism dysfunction, associated with low insulin levels in the blood. Diabetes has become a progressively more 
serious health issue in the modern world. Diabetes is the 3rd major cause of death, along with cancer, cardiovascular and cerebrovascular diseases, because of its high occurrence, morbidity, and mortality [16]. The emission of the pancreas is practically processed, and the endocrine capacity is performed by the islets of Langerhans [17-21]. These secrete insulin hormones that control metabolisms, but their main function is to control sugar levels in the blood. ATP-sensitive $\mathrm{K}^{+}$channels establish the membrane potential in $\beta$-cells [22]. Insulin regulates metabolic reaction after binding with a receptor-like breakdown of glucose its conversion to glycogen and fats metabolism [23,24].

Hypoglycemic drugs amplify insulin discharge, increase glucose uptake in fat or muscle tissue, and inhibit glucose assimilation from the gut $[25,26]$. The plants in parts or as full can be used for curing any disease associated with diabetes mellitus. Moreover, in some cases, plant extracts can treat related infections such as polyuria, polydipsia, diabetes, and other related diseases curing chronic disorders such as diabetes mellitus [27,28].

Hyperglycemia produces reactive oxidative species, which leads to lipid peroxidation and membrane deprivation. Several problems linked with diabetes, like vascular atherosclerosis, the main reason for death in diabetes mellitus, are associated with oxidative pressure. Therefore, antioxidants play a basic role in diabetic therapy [29].

Antioxidants influence the hunting of reactive oxygen species (ROS), stimulating the purification process of products and inhibiting ROS formation [30]. Various endogenous and nutritional compounds such as ferritin, superoxide dismutase transferrin, tocopherol, ascorbic acid, and carotene have antioxidant and free radical hunting properties [31-36]. Free radial attack the double bond can result in irregularity and cross-linking of DNA strands by strands meeting [37]. In recent years, biological systems have excessively developed oxidants and oxidative injuries. Studies suggested that ROS shows a key role in carcinogenesis, particularly in the promotion stage [38]. Nutritional plants have many chemical families and quantities of antioxidants [39]. ROS has a connection with over 100 diseases causing injury, infection, and acquired immunodeficiency syndrome [40]. ROS can inactivate specific enzymes by oxidation of co-factors, destruction of DNA, oxidations of amino acids and fatty acids [15,41].

Statistics show that the incidence of diabetes mellitus in Pakistan is far above the ground; it rises from $7.6 \%$ to $11 \%$ in 2011 and is projected to achieve $15.9 \%$ by 2030 . This situation will take Pakistan in 7th place in the catalog of countries with DM occurrence. If the current condition continues, Pakistan is expected to go up to fourth place. This related position cause challenge to professionals and strategy makers [12,42].

The main objective of this study was to establish the use of plant leaves extracts in controlling the DM and to assess their promising constructive effects using the streptozocininduced animal model on a scientific basis. The study was performed to evaluate antidiabetic and antioxidant activities of fruit-bearing plants, including $P$. granatum, E. japonica, and $M$. acuminata leaves using normal, and streptozocin (STZ) induced diabetic rats. In-vitro and invivo analyses were performed.

\section{Materials and Methods}

All the chemicals and reagents used in this study were of analytical grade and were purchased from Sigma Aldrich. Fresh leaves of P. granatum, E. japonica, and M. acuminata were collected in September 2018 from the Botanical garden of Government College University (GCU), Lahore. Plant leaves have been taxonomically recognized by the Botany 
department, GCU, Lahore. These authenticated plant leaves were used for the preparation of extracts.

P. granatum, E. japonica, and M. acuminata fresh leaves were isolated, dried up in the air under the shadow, and ground with a motorized grinder to make fine particles and passed through mesh size 40 and stored in air-tight bags to avoid contamination. This powdered form of leaves, almost $1.5 \mathrm{~kg}$, were soaked in methanol in the ratio of $1: 10$ and placed in an ultrasonic bath for about three to four days. Then prepared material was filtered to separate solid residue. Extracts were prepared by concentrating through vacuum distillation using a rotary evaporator at $40{ }^{\circ} \mathrm{C}$ for dryness. Extracts were further kept inside the incubator to remove moisture contents. The percentage yield of obtained crude extracts was determined. The dried extracts were packed sealed in air-tight polythene bags.

Further extraction was done with different solvents depending upon increasing polarity. These fractions were named MCE (methanolic crude extract), CFF (chloroform fraction), EAF (ethyl acetate fraction). The remaining residue left after the last fraction was also collected and labeled as an aqueous fraction (AQF). These fractions were dried and preserved at $4{ }^{\circ} \mathrm{C}$ for $i n$ vivo and in vitro analysis. The fractions were thus prepared concentrated using a rotary evaporator to get dry extracts. The percentage yields of the above fractions were calculated. Then all the samples were sealed in glass containers to avoid contamination.

Male albino Wister rats (152-185 g) were employed in this study and kept in animal houses under standard laboratory conditions ( $12 \mathrm{~h}$ dark and light cycle, $25 \pm 2{ }^{\circ} \mathrm{C}$ ). Rats were fed with a standard pellet diet and water [39].

\subsection{Preliminary phytochemical studies.}

The extracts obtained were subjected to various tests for further selection to be used for hypoglycemic, antiperoxidative, and prevention of weight loss studies. Harborne protocol was followed to check the availability of phenols qualitatively. Plant leaves extracts were mixed with $10 \% \mathrm{FeCl}_{3}$ solution and $2 \mathrm{~mL}$ of water. Phenols are confirmed by the appearance of blue or green coloration [43]. A few drops of Mayer's reagent were mixed with $\mathrm{H}_{2} \mathrm{SO}_{4}$ and $2 \mathrm{mg}$ of plant leaves extracts. The presence of alkaloids is confirmed by the endpoint: green color appearance or white precipitate formation [44].

Alkaloids availability was tested by performing the following methods. Wagner's test was performed by mixing Wagner's reagent with $2 \mathrm{mg}$ of sample extract after acidification with $1.5 \% \mathrm{HCl}$. Iodine and potassium iodide were also mixed to check the alkaloid's availability by its color change which may be yellow or brown [45]. The following protocol was adopted for the Mayer test, a few drops of Mayer reagent were mixed with mercuric chloride, potassium iodide, and $2 \mathrm{mg}$ of sample extracts. The presence of alkaloids is confirmed by the endpoint, which is pale yellow or white precipitate formation.

For Fehling's test, $2 \mathrm{mg}$ of plant extracts were taken in a glass test tube and shaken thoroughly with water. After that small amount of Fehling's solutions (A \& B) was added and heated gently. Brick red precipitates (ppts) showed the presence of carbohydrates [31]. For the Molisch test, $2 \mathrm{mg}$ of plant leaves partitions were shaken few drops of freshly prepared $\alpha$ naphthol and conc. $\mathrm{H}_{2} \mathrm{SO}_{4}$ was poured drop by drop, formation of a red-violet ring showed the carbohydrates and glycosides were present. In the Ninhydrin test, the measured quantity of samples was mixed with distilled water to make an original solution and then mixed with ninhydrin reagent. The purple color indicates the availability of protein and peptides linkages. 
Foam Test was performed by shaking $5 \mathrm{mg}$ of plant extracts with a few drops of $\mathrm{NaHCO}_{3}$ vigorously and left to rest honeycomb-like froth formation indicates saponins. Salkowski test was performed to check the sterols, $2 \mathrm{mg}$ of plant extract was mixed with chloroform, then $\mathrm{H}_{2} \mathrm{SO}_{4}$ layer was poured along the wall of test tube slowly, red color appearance indicates sterol [31]. To check the availability of tannins, Lead acetate mixed with $2 \mathrm{mg}$ of plant extract and formation of white ppt's showing tannins and phenolic compounds presence. $\mathrm{NaOH}$ and $\mathrm{H}_{2} \mathrm{SO}_{4}$ Test was conducted to check flavonoids which show yellow color with $\mathrm{NaOH}$ and yellow-orange color with concentrated sulfuric acid [45].

\subsection{Antioxidant in-vitro analysis.}

Fractions of plant leaf extracts of $P$. granatum, E. japonica, and M. acuminata were subjected to in vitro study of antioxidant action.

\subsubsection{DPPH free radical scavenging activity.}

The plant leaves extracts were studied for DPPH (2,2-diphenyl-1-picrylhydrazyl) scavenging action. For the preparation of extract solutions, $0.05 \mathrm{~g}$ dry extract was added in 50 $\mathrm{mL}$ of methyl alcohol. Two $\mathrm{mL}$ of $0.004 \% \mathrm{DPPH}$ solution were mixed in methyl alcohol, and $1 \mathrm{~mL}$ of plant extract in methanol was added, and incubation was done at $25{ }^{\circ} \mathrm{C}$ for half an hour. The spectrophotometer was used to check the absorbance at $517 \mathrm{~nm}$, and $1 \mathrm{~mL}$ of methanol was used as DPPH control instead of extract. Purple-colored DPPH is a stable free radical, which becomes yellow upon reduction by converting into diphenyl picrylhydrazine. All the experiments were done in triplicate to calculate the average value. The standard used in this experiment was ascorbic acid. The inhibition $(\%)$ was determined by the given equation:

$$
\text { Percentage Inhibition }=\frac{A_{b}-A_{s}}{A_{b}} \times 100
$$

where $\mathrm{A}_{\mathrm{b}}$ stands for absorption of the blank and $\mathrm{A}_{\mathrm{s}}$ for the absorption of the extract solution under study [46-51].

\subsubsection{Hydrogen peroxide scavenging activity.}

The leaves extract of $P$. granatum, E. japonica, and $M$. acuminata were dissolved in methanol to prepare a $1 \mathrm{mg} / \mathrm{mL}$ reserve solution. Varying concentration of reserve solutions $(0.2,0.4,0.6,0.8$, and $1 \mathrm{mg} / \mathrm{mL})$ mixed to $3.8 \mathrm{~mL}$ of $0.1 \mathrm{M}$ solution of phosphate buffer having $\mathrm{pH}$ of 7.4, also mixed with $0.2 \mathrm{~mL}$ of $\mathrm{H}_{2} \mathrm{O}_{2}$. Mixture without sample was used as blank, whereas ascorbic acid acts as standard [52] percentage inhibition of hydrogen peroxide was determined with the following formula.

$$
\text { Percentage Inhibition }=\frac{A_{c}-A_{s}}{A_{c}} \times 100
$$

where $\mathrm{A}_{\mathrm{c}}$ stands for $\mathrm{A}_{\mathrm{control}}$ and $\mathrm{A}_{\mathrm{s}}$ stands for $\mathrm{A}_{\text {sample. }}$

\subsection{Antidiabetic and $\alpha$-amylase inhibition activity, in vitro analysis.}

A method to cure diabetes type II is to reduce the postprandial glucose level of blood by inhibiting carbohydrate hydrolyzing enzyme. Pancreatic alpha-amylase inhibitors stop starch breaking and absorption by lowering postprandial glucose blood levels and weight loss.

The alpha-amylase enzyme is accountable for polysaccharides' metabolism, such as starch, carbohydrates, etc. The present research is commenced to assess the change in the 
reaction rate by the effect of $\alpha$-amylase concentration and inhibiting ability of methanolic leaves extracts of $P$. granatum, E. japonica, and M. acuminata and their fractions [29].

$\alpha$-amylase inhibition assay was carried out by 3,5 -dinitrosalicylic acid (DNSA) method. Plant leaves extract was mixed with a small amount of dimethylsulphoxide (DMSO) solution of $10 \%$ and then mixed with a buffer of sodium biphosphate, sodium phosphate, and sodium chloride of $\mathrm{pH} 6.8$ to get the required quantity of the solution. Then $200 \mu \mathrm{L}$ solution of alphaamylase was mixed with $200 \mu \mathrm{L}$ of plant leaves extract and incubated at $30{ }^{\circ} \mathrm{C}$ for about ten min. Then $200 \mu \mathrm{L}$ starch solution was taken in a test tube and was incubated for three min. and the reaction was stopped by DSNA addition and heated for ten min. in the water bath at 85-90 ${ }^{\circ} \mathrm{C}$. Then the solution was cooled and diluted, and its absorbance was calculated at $540 \mathrm{~nm}$ by an ultraviolet-visible spectrometer, then the percentage of alpha-amylase was drawn in the form of a graph and the following formula was used to calculate the percent inhibition of $\alpha$ amylase activity [53].

$$
\alpha-\text { amylase inhibition }(\%)=\frac{A_{100 \% \text { control }-A_{\text {sample }}}}{A_{100 \% \text { control }}} \times 100
$$

\subsection{Hypoglycemic study of plant leaf extracts in vivo analysis.}

2.4.1. P. granatum leaves extracts in normal fasted rats.

On the basis of results obtained from alpha-amylase and antioxidant activity of leaves extracts study, ethyl acetate, aqueous, and crude extract of methanol were selected due to their better activity than that of other fractions of the same plant. All the dosing was carried out via stainless steel (intragastric bulb) feeding tube. To study the hypoglycemic effects, fasted rats were classified into 5 groups, and each group contained six rats; G-I: Control group, G-II: Standard control (Glimepiride-2 mg/kg), G-III: Methanolic crude extract (50 mg/kg), G-IV: Ethyl acetate fraction $(50 \mathrm{mg} / \mathrm{kg})$ and G-V: Aqueous fraction $(50 \mathrm{mg} / \mathrm{kg})$.

\subsubsection{E. japonica and M. acuminata leaves extract in normal fasted rats.}

On the basis of results obtained from alpha-amylase and antioxidant profile of leaves extracts, chloroform, aqueous, and crude extract of methanol were selected due to their better activity than that of other fractions for the E. japonica. Similarly, for the M. acuminata, fractions of ethyl acetate, aqueous, and crude extract of methanol were selected [23], and the same experiment was repeated as above.

\subsection{Oral glucose tolerance test (OGTT).}

On the basis of results obtained from alpha-amylase and antioxidant activity of leaves extracts study, ethyl acetate, aqueous, and crude extract of methanol were selected due to their better activity than that of other fractions of the same plant. An oral glucose tolerance test was performed in overnight fasted rats. After $30 \mathrm{~min}$ of administering all selected leaves extracts, rats were fed with $2 \mathrm{~g} / \mathrm{kg}$ glucose orally. Samples of the blood of rats were collected from the tail vein by a sterile syringe after regular intervals and were checked using a digital glucometer [54]. Similarly, for the M. acuminata, fractions of ethyl acetate, aqueous, and crude extract of methanol were selected, and the same experiment was repeated as above. 
2.6. Experimental induction of diabetes mellitus in rats.

Induced hyperglycemia (elevated blood sugar level) is a very helpful experimental design to observe the efficacy of hypoglycemic agents under study. DM was induced artificially in all night fasted rats, having complete access to water, by injecting a single dose of $40 \mathrm{mg} / \mathrm{kg}$ (of rat body weight) of streptozocin (STZ) dissolved in $0.1 \mathrm{M}$ Trisodium citrate $\left(\mathrm{Na}_{3} \mathrm{C}_{6} \mathrm{H}_{5} \mathrm{O}_{7}\right)$ buffer having $\mathrm{pH} 4.5$, intraperitoneal. After injection rats were set free for water and food. The rats were fed with glucose solution ( $5 \%$ ) to come out from hypoglycemia shock. After $48 \mathrm{~h}$ of injecting streptozocin, diabetes was confirmed. The rats showing fasting glucose reading greater than $200 \mathrm{mg} / \mathrm{dL}$ were found to be diabetic and hence used in this research onwards.

\subsubsection{Experimental design.}

After 3 days of diabetes induction, rats were devised into six groups, each with six rats. Nondiabetic rats were tagged as a control group. Each group was provided with the following treatment for 28 days. G-I: Control group (Nondiabetic); G-II: Diabetic Controls rats; G-III: Standard control group (Glimepiride $2 \mathrm{mg} / \mathrm{kg}$ ); G-IV: Methanolic crude extract of plant leaves (50 mg/kg), G-V: Ethyl Acetate/Chloroform fraction of plant leaves $(50 \mathrm{mg} / \mathrm{kg}$ ) and G-VI: Aqueous fraction of plant leaves $(50 \mathrm{mg} / \mathrm{kg})$. Experimental and control groups rats were treated accordingly on a daily basis for 28 days without interruption. The chloroform fraction was selected for E. japonica only due to its better activity. The body weights of rats were recorded five times during the study on $0,7,14,21$, and $28^{\text {th }}$ days of the treatment period by digital weighing balance [55]. Blood samples from both experimental and control group rats were collected after seven days intervals during 28 days five times (days $0,7,14,21$, and 28).

\subsection{Biochemical parameter study in liver tissues in vivo analysis.}

On the $28^{\text {th }}$ day, the rats were made to fast for $12 \mathrm{~h}$, mildly anesthetized by diethyl ether, and sacrificed. After dissection liver tissue sample was rinsed with ice cold normal saline. The sample was homogenized with phosphate $\left(\mathrm{PO}_{4}{ }^{3-}\right)$ buffer $(25 \mathrm{mM}$ of $7.4 \mathrm{pH})$ in order to make $10 \%$ weight/volume liver homogenate. It was centrifuged at a speed of $1700 \mathrm{rpm}$ for ten min. The supernatant (S) was collected and kept at $-20^{\circ} \mathrm{C}$ for further biomarker evaluation [55]. The tissue homogenate $(10 \% \mathrm{w} / \mathrm{v})$ thus prepared was used for the assay of lipid peroxidation [56], superoxide dismutase assay [57], and catalase assay [58].

\subsubsection{Lipid peroxidation (LPO) assay.}

The amount of thiobarbituric acid reactive substances (TBARS) in the liver was calculated by lipid peroxidation product malondialdehyde (MDA). $1 \mathrm{~mL}$ of the sample was mixed with $0.2 \mathrm{~mL}(4 \% \mathrm{w} / \mathrm{v})$ sodium dodecyl sulfate, $1.5 \mathrm{~mL}(20 \%$ acetic acid in $0.27 \mathrm{M}$ hydrochloric acid having $\mathrm{pH} 3.5$ ), and $1.5 \mathrm{~mL}$ of $0.8 \%$ thiobarbituric acid (pH 7.4). Then it was boiled in a hot water bath at $85^{\circ} \mathrm{C}$ for about 1 hour. The appearance of pink color was studied against blank at a wavelength of $532 \mathrm{~nm}$. Then centrifugation was done at $1200 \mathrm{rpm}$ for $10 \mathrm{~min}$. For the standardization, tetra ethoxy propane was used. The concentrations are denoted as $\mathrm{mM} / 100 \mathrm{~g}$. 
2.7.2. Superoxide dismutase (SOD) assay.

In this procedure, the assay mixture contains $1.2 \mathrm{~mL}$ sodium pyrophosphate buffer $(\mathrm{pH}$ 8.3, $0.025 \mathrm{M}), \quad 0.1 \mathrm{~mL}(186 \mu \mathrm{M})$ phenazinemetho sulfate, $0.3 \mathrm{~mL}(300 \mu \mathrm{m})$ nitrobluetetrazolium, $0.2 \mathrm{~mL} \mathrm{NADH}(780 \mu \mathrm{m})$, approximately diluted enzyme preparation is added with water and make up a total volume of $3 \mathrm{~mL}$. This was then incubated at $30{ }^{\circ} \mathrm{C}$ for 90 seconds. Then glacial acetic acid was added to stop the reaction. The fusion was robustly shaken with $4 \mathrm{~mL}$ of butyl alcohol. Then the mixture was allowed to stand for about $10 \mathrm{~min}$ and then centrifuged to separate butyl alcohol. Chromogens color intensity in the butyl alcohol as observed at $560 \mathrm{~nm}$. A system devoid of enzymes serves as a control. One unit of the enzyme activity is defined as the enzyme concentration necessary to stop the optical density at 560nm of chromogen production by $50 \%$ in 60 seconds under the assay conditions and showed specific activity in milli units/mg wet tissue.

\subsubsection{Catalase (CAT) assay.}

To $0.9 \mathrm{ml}$ of phosphate buffer, $0.1 \mathrm{~mL}$ homogenate (liver tissue) and $0.4 \mathrm{~mL}$ of $\mathrm{H}_{2} \mathrm{O}_{2}$ were added. After 60 seconds, $2 \mathrm{~mL}$ of dichromate acetic acid mixture was also added. The glass test tubes were kept in a water bath containing boiled water for about $10 \mathrm{~min}$, and color was produced and studied at $620 \mathrm{~nm} .2-10 \mu \mathrm{M}$ concentration was used as standard and preceded for the further test with blank containing reagent alone. The activity was expressed as units/g tissue [59].

\subsection{Statistical analysis of recorded data.}

Collected data were recorded as mean \pm SEM and was estimated by using two-way ANOVA (analysis of variance) followed by Dunnett's method for many times comparisons. The significant difference was checked by using a $\mathrm{p}$-value of $\mathrm{P} \leq 0.05[60,61]$.

\section{Results and Discussion}

Herbal extracts of leaves of $P$. granatum, E. japonica, and $M$. acuminata were prepared, and their various fractionates like methanolic crude extract (MCE), chloroform fraction (CFF), ethyl ethanoate fraction (EAF), and water fraction (AQF) were used for curing the diabetic rats, for checking the antidiabetic and antioxidant activities of these leaves extracts for the protection to human being from hyperglycemia in future. Leaves extracts of P. granatum, E. japonica, and $M$. acuminata were prepared with methanol chloroform, ethyl acetate, and water. Table 1 shows the yield of extracts in various solvents. The qualitative chemical investigation of the all-selected plant leaves and their phytoconstituents results by performing various chemical reactions shown in Table 2. Various fractions show the different extent of activities. Hence, further pharmacological studies were performed for P. granatum, E. japonica, and $M$. acuminata extracts.

Table 1. Extractive values of leaves extracts of plants in different solvent systems.

\begin{tabular}{c|c|c|c|c}
\multirow{2}{*}{ Plants } & \multicolumn{4}{|c}{ Yield in percentage (w/w) } \\
\cline { 2 - 4 } & MCE & CFF & EAF & AQF \\
\hline P. granatum & $8.65 \%$ & $17.18 \%$ & $10.45 \%$ & $64.25 \%$ \\
\hline E. japonica & $4.88 \%$ & $11.15 \%$ & $57.29 \%$ & $25.21 \%$ \\
\hline M. acuminata \\
Percentage yield of fractions = weight of fraction/weight of crude extract x 100.
\end{tabular}


Table 2. Phytochemical analysis of methanolic leaves extracts of plants and their fractions.

\begin{tabular}{|c|c|c|c|c|c|c|}
\hline Plants & Constituents Tested & Test & MCE & CFF & EAF & AQF \\
\hline \multirow{10}{*}{ 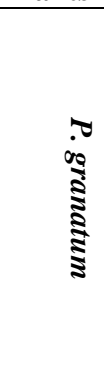 } & \multirow[t]{2}{*}{ Alkaloids } & Mayer's test & - & + & + & - \\
\hline & & Wagner's test & - & + & + & - \\
\hline & \multirow[t]{2}{*}{ Carbohydrates } & Molisch's test & - & + & + & + \\
\hline & & Fehling's test & - & + & + & + \\
\hline & Phenolic compounds & Lead acetate test & - & + & + & + \\
\hline & Proteins & Ninhydrin test & - & - & - & - \\
\hline & \multirow[t]{2}{*}{ Sterols } & Salwoski's test & - & - & + & + \\
\hline & & Foam test & + & - & + & + \\
\hline & \multirow[t]{2}{*}{ Flavonoids } & Aq. \& $\mathrm{NaOH}$ & - & - & + & + \\
\hline & & Conc. $\mathrm{H}_{2} \mathrm{SO}_{4}$ & - & - & + & + \\
\hline \multirow{10}{*}{ 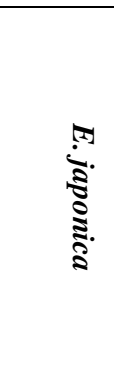 } & \multirow[t]{2}{*}{ Alkaloids } & Mayer's test & - & + & + & - \\
\hline & & Wagner's test & - & + & + & - \\
\hline & \multirow{2}{*}{ Carbohydrates } & Molisch's test & - & + & + & + \\
\hline & & Fehling's test & - & + & + & + \\
\hline & Phenolic compounds & Lead acetate test & - & + & + & + \\
\hline & Proteins & Ninhydrin test & - & - & - & - \\
\hline & \multirow[t]{2}{*}{ Sterols } & Salwoski's test & - & - & + & + \\
\hline & & Foam test & + & - & + & + \\
\hline & \multirow[t]{2}{*}{ Flavonoids } & Aq. \& $\mathrm{NaOH}$ & - & - & + & + \\
\hline & & Conc. $\mathrm{H}_{2} \mathrm{SO}_{4}$ & - & - & + & + \\
\hline \multirow{10}{*}{ 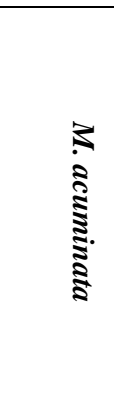 } & \multirow[t]{2}{*}{ Alkaloids } & Mayer's test & - & + & + & - \\
\hline & & Wagner's test & - & + & + & - \\
\hline & \multirow[t]{2}{*}{ Carbohydrates } & Molisch's test & - & + & + & + \\
\hline & & Fehling's test & - & + & + & + \\
\hline & Phenolic compounds & Lead acetate test & - & + & + & + \\
\hline & Proteins & Ninhydrin test & - & - & - & - \\
\hline & \multirow[t]{2}{*}{ Sterols } & Salwoski's test & - & - & + & + \\
\hline & & Foam test & + & - & + & + \\
\hline & \multirow[t]{2}{*}{ Flavonoids } & Aq. \& $\mathrm{NaOH}$ & - & - & + & + \\
\hline & & Conc. $\mathrm{H}_{2} \mathrm{SO}_{4}$ & - & - & + & + \\
\hline
\end{tabular}

Presence (+); Absence (-).

\subsection{In vitro antioxidant activity.}

\subsubsection{DPPH method.}

The DPPH inhibition percentage scavenging activity of methanolic crude extract of leaves of $P$. granatum, E. japonica, and $M$. acuminata and their fractions is presented in Table 3. The methanolic extracts of $P$. granatum exhibited a maximum scavenging activity of 62.17 $\%$ at $100 \mu \mathrm{g} / \mathrm{mL}$, whereas for ascorbic acid, it was $85.68 \%$, and fraction for ethyl acetate was $80.63 \%$. The chloroform fraction of E. japonica leaves has exhibited maximum scavenging behavior of $79.86 \%$ at $100 \mu \mathrm{g} / \mathrm{mL}$. Ethyl acetate fraction for $M$. acuminata has exhibited maximum scavenging activity of $77.68 \%$. The methanolic extracts of $M$. acuminata exhibited a minimum scavenging activity of $60.91 \%$ at $100 \mu \mathrm{g} / \mathrm{mL}$. The same results were proposed by Patil et al. [62].

\subsection{2. $\mathrm{H}_{2} \mathrm{O}_{2}$ scavenging activity.}

The percentage inhibition of $\mathrm{H}_{2} \mathrm{O}_{2}$ activity of various natural products of $P$. granatum, E. japonica, and $M$. acuminata has been presented in Table 3. The methanolic extracts of $P$. granatum exhibited a maximum scavenging activity of $59.21 \%$ at $100 \mu \mathrm{g} / \mathrm{mL}$, whereas ascorbic acid (standard) was found to be $83.12 \%$. Ethyl acetate extract of $P$. granatum has shown a maximum scavenging response of $71.46 \%$. The chloroform fraction of E. japonica extract has exhibited maximum scavenging activity of $70.02 \%$. Ethyl acetate extract of $M$. 
acuminata has exhibited maximum scavenging activity of $73.06 \%$. The methanolic crude extract of M. acuminata exhibited a minimum scavenging activity of $56.11 \%$ [63].

Table 3. Free radical scavenging action of leaves extracts of plants and their fractions by DPPH method and by $\mathrm{H}_{2} \mathrm{O}_{2}$ method.

\begin{tabular}{|c|c|c|c|c|c|c|}
\hline \multirow{2}{*}{ 휼 } & \multirow{2}{*}{ 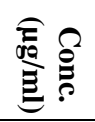 } & \multicolumn{5}{|c|}{ \% Inhibition (DPPH) } \\
\hline & & MCE & CFF & EAF & $\mathrm{AQF}$ & $\begin{array}{c}\text { Standard } \\
\text { (Ascorbic Acid) }\end{array}$ \\
\hline \multirow{5}{*}{ 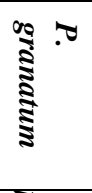 } & 20 & $12.52 \pm 0.31$ & $9.11 \pm 0.57$ & $18.32 \pm 0.29$ & $11.16 \pm 0.18$ & $29.32 \pm 0.36$ \\
\hline & 40 & $21.43 \pm 0.27$ & $23.83 \pm 0.19$ & $43.52 \pm 0.46$ & $22.25 \pm 0.37$ & $46.54 \pm 0.48$ \\
\hline & 60 & $39.26 \pm 0.12$ & $31.29 \pm 0.47$ & $56.23 \pm 0.59$ & $35.19 \pm 0.34$ & $60.81 \pm 0.57$ \\
\hline & 80 & $50.69 \pm 0.51$ & $39.73 \pm 0.12$ & $69.92 \pm 0 . .65$ & $57.49 \pm 0.69$ & $74.25 \pm 0.28$ \\
\hline & 100 & $62.17 \pm 0.63$ & $46.67 \pm 0.32$ & $80.63 \pm 0.47$ & $69.79 \pm 0.77$ & $85.68 \pm 0.63$ \\
\hline \multirow{5}{*}{ 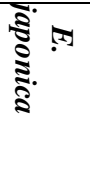 } & 20 & $13.11 \pm 0.13$ & $16.49 \pm 0.22$ & $10.14 \pm 0.24$ & $12.26 \pm 0.11$ & $29.32 \pm 0.36$ \\
\hline & 40 & $24.19 \pm 0.29$ & $35.25 \pm 0.75$ & $22.93 \pm 0.15$ & $23.12 \pm 0.45$ & $46.54 \pm 0.48$ \\
\hline & 60 & $38.59 \pm 0.42$ & $53.61 \pm 0.29$ & $29.19 \pm 0.36$ & $39.26 \pm 0.49$ & $60.81 \pm 0.57$ \\
\hline & 80 & $51.39 \pm 0.58$ & $62.64 \pm 0.32$ & $35.79 \pm 0.22$ & $53.53 \pm 0.72$ & $74.25 \pm 0.28$ \\
\hline & 100 & $61.59 \pm 0.87$ & $79.86 \pm 0.83$ & $49.91 \pm 0.48$ & $66.91 \pm 0.56$ & $85.68 \pm 0.63$ \\
\hline \multirow{5}{*}{ 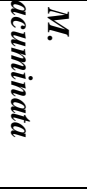 } & 20 & $11.67 \pm 0.21$ & $7.16 \pm 0.75$ & $13.39 \pm 0.27$ & $15.29 \pm 0.41$ & $29.32 \pm 0.36$ \\
\hline & 40 & $19.21 \pm 0.45$ & $19.38 \pm 0.17$ & $29.15 \pm 0.64$ & $26.72 \pm 0.25$ & $46.54 \pm 0.48$ \\
\hline & 60 & $34.62 \pm 0.39$ & $27.92 \pm 0.74$ & $41.31 \pm 0.19$ & $35.67 \pm 0.94$ & $60.81 \pm 0.57$ \\
\hline & 80 & $50.33 \pm 0.72$ & $33.83 \pm 0.51$ & $63.54 \pm 0.22$ & $49.91 \pm 0.12$ & $74.25 \pm 0.28$ \\
\hline & 100 & $60.91 \pm 0.46$ & $42.76 \pm 0.23$ & $77.68 \pm 0.38$ & $68.81 \pm 0.26$ & $85.68 \pm 0.63$ \\
\hline \multicolumn{7}{|c|}{$\%$ Inhibition $\left(\mathbf{H}_{2} \mathbf{O}_{2}\right)$} \\
\hline \multirow{5}{*}{ 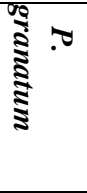 } & 20 & $24.75 \pm 1.32$ & $8.22 \pm 1.44$ & $15.13 \pm 0.86$ & $8.44 \pm 0.92$ & $23.49 \pm 0.91$ \\
\hline & 40 & $33.72 \pm 1.61$ & $15.37 \pm 1.18$ & $24.69 \pm 0.44$ & $18.60 \pm 1.77$ & $49.10 \pm 2.06$ \\
\hline & 60 & $44.33 \pm 2.15$ & $20.11 \pm 0.03$ & $39.29 \pm 2.37$ & $29.73 \pm 1.17$ & $55.17 \pm 2.42$ \\
\hline & 80 & $52.98 \pm 1.98$ & $27.28 \pm 0.71$ & $51.24 \pm 1.79$ & $47.88 \pm 1.89$ & $71.93 \pm 3.98$ \\
\hline & 100 & $59.21 \pm 1.92$ & $35.75 \pm 1.52$ & $71.46 \pm 2.07$ & $61.38 \pm 2.39$ & $83.12 \pm 2.65$ \\
\hline \multirow{5}{*}{$\begin{array}{l}\text { हैं } \\
\text { §. } \\
\text { §. }\end{array}$} & 20 & $19.45 \pm 1.12$ & $23.33 \pm 0.81$ & $7.32 \pm 1.04$ & $13.34 \pm 0.12$ & $23.49 \pm 0.91$ \\
\hline & 40 & $29.92 \pm 1.21$ & $31.39 \pm 0.49$ & $13.77 \pm 1.48$ & $23.80 \pm 1.97$ & $49.10 \pm 2.06$ \\
\hline & 60 & $38.53 \pm 2.35$ & $43.79 \pm 2.35$ & $17.91 \pm 0.13$ & $31.63 \pm 1.37$ & $55.17 \pm 2.42$ \\
\hline & 80 & $49.88 \pm 1.48$ & $57.17 \pm 1.19$ & $23.38 \pm 0.51$ & $49.78 \pm 1.59$ & $71.93 \pm 3.98$ \\
\hline & 100 & $58.11 \pm 1.62$ & $70.02 \pm 2.02$ & $31.85 \pm 1.22$ & $60.33 \pm 2.89$ & $83.12 \pm 2.65$ \\
\hline \multirow{5}{*}{ 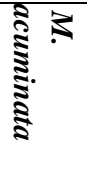 } & 20 & $24.45 \pm 1.12$ & $8.42 \pm 1.94$ & $17.33 \pm 0.46$ & $16.34 \pm 0.92$ & $23.49 \pm 0.91$ \\
\hline & 40 & $32.92 \pm 1.21$ & $11.37 \pm 1.88$ & $27.69 \pm 0.34$ & $25.10 \pm 1.57$ & $49.10 \pm 2.06$ \\
\hline & 60 & $41.53 \pm 2.35$ & $19.21 \pm 0.73$ & $42.09 \pm 2.07$ & $39.73 \pm 1.67$ & $55.17 \pm 2.42$ \\
\hline & 80 & $49.88 \pm 1.48$ & $27.18 \pm 0.61$ & $54.84 \pm 1.79$ & $52.18 \pm 1.59$ & $71.93 \pm 3.98$ \\
\hline & 100 & $56.11 \pm 1.62$ & $35.05 \pm 1.52$ & $73.06 \pm 2.27$ & $63.23 \pm 2.09$ & $83.12 \pm 2.65$ \\
\hline
\end{tabular}

3.2. In vitro antidiabetic and $\alpha$-amylase inhibition activity.

The $\alpha$-amylase helps in the digestion of starch into simple glucose molecules. Breakdown of glucose increases with a decrease in glucose level inside the blood and decreases as blood glucose concentration increases. It means the rate of digestion of starch molecules or other carbohydrates is dependent on the presence or absence of $\alpha$-amylase. The present study reveals the inhibition of $\alpha$-amylase by methanolic crude extract and leaves fractions of $P$. granatum, E. japonica, and $M$. acuminata. Statistical analysis revealed that the methanolic extracts of $P$. granatum, E. japonica, and $M$. acuminata showed significant digestion. A study [64] proposed that ethyl ethanoate and water contain fractions of $P$. granatum, chloroform, and aqueous fractions of E. japonica, and ethyl ethanoate and water containing fractions of $M$. acuminata exhibited better results than other fractions of plant leaves. Hence these fractions were used for further in vivo studies. The results are presented in Table 4. 
Table 4. $\alpha$ - amylase inhibition assay for control and standard drug and for methanolic extracts and its fractions for plants leaves under study.

\begin{tabular}{|c|c|c|c|c|c|c|}
\hline Tubes & Test solution & $\begin{array}{c}\text { Buffer (pH } \\
6.8) \\
\end{array}$ & \multicolumn{4}{|c|}{ Time till starch vanish (min) } \\
\hline \multirow{4}{*}{ 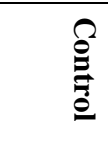 } & $0.5 \mathrm{ml}$ starch soln. $+0.25 \% \alpha$-amylase soln. & \multirow[t]{21}{*}{20 drops } & \multicolumn{4}{|c|}{13} \\
\hline & $0.5 \mathrm{ml}$ starch soln. $+0.5 \% \alpha$-amylase soln. & & \multicolumn{4}{|c|}{11} \\
\hline & $0.5 \mathrm{ml}$ starch soln. $+1 \% \alpha$-amylase soln. & & \multicolumn{4}{|c|}{09} \\
\hline & $0.5 \mathrm{ml}$ starch soln. $+2 \% \quad \alpha$-amylase soln.. & & \multicolumn{4}{|c|}{07} \\
\hline \multirow{4}{*}{ 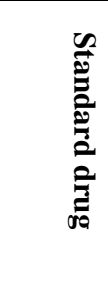 } & $\begin{array}{l}0.5 \mathrm{ml} \text { starch soln. }+1 \% \alpha \text {-amylase soln. }+0.25 \% \\
\text { glimepiride soln.. }\end{array}$ & & \multicolumn{4}{|c|}{16} \\
\hline & $\begin{array}{c}0.5 \mathrm{ml} \text { starch soln. }+1 \% \alpha \text {-amylase soln. }+0.5 \% \text { glimepiride } \\
\text { soln. }\end{array}$ & & \multicolumn{4}{|c|}{19} \\
\hline & $\begin{array}{c}0.5 \mathrm{ml} \text { starch soln. }+1 \% \alpha \text {-amylase soln. }+1 \% \text { glimepiride } \\
\text { soln. }\end{array}$ & & \multicolumn{4}{|c|}{21} \\
\hline & $\begin{array}{c}0.5 \mathrm{ml} \text { starch soln. }+1 \% \alpha \text {-amylase soln. }+2 \% \text { glimepiride } \\
\text { soln. }\end{array}$ & & \multicolumn{4}{|c|}{24} \\
\hline Plants & $\begin{array}{c}\text { Test solution } \\
\end{array}$ & & MCE & CFF & EAF & $\mathbf{A Q F}$ \\
\hline \multirow{4}{*}{ 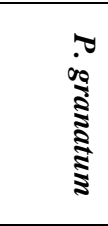 } & $\begin{array}{c}0.5 \mathrm{ml} \text { starch soln. }+1 \% \alpha \text {-amylase soln. }+0.25 \% \text { leaves } \\
\text { extract }\end{array}$ & & 10 & 8 & 12 & 11 \\
\hline & $\begin{array}{c}0.5 \mathrm{ml} \text { starch soln. }+1 \% \alpha \text {-amylase soln. }+0.5 \% \text { leaves } \\
\text { extract }\end{array}$ & & 12 & 10 & 19 & 16 \\
\hline & $0.5 \mathrm{ml}$ starch soln. $+1 \% \alpha$-amylase soln. $+1 \%$ leaves extract & & 15 & 13 & 21 & 18 \\
\hline & $0.5 \mathrm{ml}$ starch soln. $+1 \% \alpha$-amylase soln. $+2 \%$ leaves extract & & 17 & 15 & 23 & 20 \\
\hline \multirow{4}{*}{ 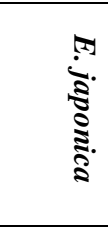 } & $\begin{array}{c}0.5 \mathrm{ml} \text { starch soln. }+1 \% \\
\text { extract }\end{array}$ & & 12 & 7 & 10 & 13 \\
\hline & $\begin{array}{c}0.5 \mathrm{ml} \text { starch soln. }+1 \% \alpha \text {-amylase soln. }+0.5 \% \text { leaves } \\
\text { extract }\end{array}$ & & 15 & 9 & 16 & 15 \\
\hline & $0.5 \mathrm{ml}$ starch soln. $+1 \% \alpha$-amylase soln. $+1 \%$ leaves extract & & 16 & 14 & 20 & 17 \\
\hline & $0.5 \mathrm{ml}$ starch soln. $+1 \% \alpha$-amylase soln. $+2 \%$ leaves extract & & 18 & 16 & 22 & 19 \\
\hline \multirow{4}{*}{ 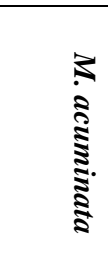 } & $\begin{array}{c}0.5 \mathrm{ml} \text { starch soln. }+1 \% \\
\begin{array}{c}\alpha \text {-amylase soln. }+0.25 \% \text { leaves } \\
\text { extract }\end{array}\end{array}$ & & 19 & 7 & 13 & 10 \\
\hline & $\begin{array}{c}0.5 \mathrm{ml} \text { starch soln. }+1 \% \alpha \text {-amylase soln. }+0.5 \% \text { leaves } \\
\text { extract }\end{array}$ & & 13 & 10 & 17 & 15 \\
\hline & $0.5 \mathrm{ml}$ starch soln. $+1 \% \alpha$-amylase soln. $+1 \%$ leaves extract & & 17 & 12 & 23 & 19 \\
\hline & $\begin{array}{c}0.5 \mathrm{ml} \text { starch soln. }+1 \% \alpha \text {-amylase soln. }+2 \% \text { leaves } \\
\text { extract }\end{array}$ & & 18 & 14 & 25 & 21 \\
\hline
\end{tabular}

Abbreviations: MCE; Methanolic crude extract: CFF; chloroform fraction: EAF; ethyl acetate fraction: AQF; aqueous fraction: soln.; solution: conc.; concentration.

\subsection{In vivo antidiabetic activity analysis}

\subsubsection{Hypoglycemic study in normal fasted rats.}

The blood sugar level in normal rats subjected to a single dose of methanolic crude extract of $P$. granatum, E. japonica, and $M$. acuminata and their fractions at a $50 \mathrm{mg} / \mathrm{kg}$ dose showed no significant hypoglycemic effects after $3^{\text {rd }}$ hour. The standard drug glimepiride (2 $\mathrm{mg} / \mathrm{kg}$ ) also showed no significant hypoglycemic effect at $3^{\text {rd }}$ hour after oral administration and restored the normal level shown in Table 5.

\subsubsection{Oral glucose tolerance test (OGTT).}

Glucose, when injected in the dosage of $2 \mathrm{~g} / \mathrm{kg}$, exhibits a rise in the sugar concentration in rats' blood (normal) after half-hour of the dose given orally. In experimental rats treated with leaves extracts and standard drugs, the blood sugar level peaked at half an hour and returned to normal at the end of $2 \mathrm{~h}$. The maximum hypo-glycemic effect of ethyl acetate fraction of $P$. granatum $(50 \mathrm{mg} / \mathrm{kg}$ ) was found to be 80.73 to $135.74,100.15$ to 92.59 . The maximum hypoglycemic effect of chloroform fraction of E. japonica $(50 \mathrm{mg} / \mathrm{kg}$ ) was found to be 79.49 to $137.58,103.39$ to 94.07 . The maximum hypoglycemic effect of ethyl acetate fraction of $M$. acuminata $(50 \mathrm{mg} / \mathrm{kg}$ ) was found to be 80.14 to $139.68,106.56$ to 97.34 . Administration of methanolic extract (crude) and its selected components significantly decreases the sugar level 
in comparison to normal control rats, as the same results were also discussed [55]. OGTT experimental results are presented in Table 6 and Figure 1.

Table 5. Hypoglycemic effect of methanolic leaves extracts of plants and their fractions in normal rats.

\begin{tabular}{|c|c|c|c|c|c|}
\hline \multirow[t]{2}{*}{ Group } & \multirow[t]{2}{*}{ Treatment } & \multicolumn{4}{|c|}{ Blood sugar level (mg/dL) } \\
\hline & & Ohr & 1hr & $2 \mathrm{hr}$ & $3 \mathrm{hr}$ \\
\hline \multirow{2}{*}{$\approx \frac{\tilde{\Sigma}}{\mathfrak{\Sigma}}$} & Control group & $78.26 \pm 0.93$ & $79.35 \pm 0.85$ & $81.40 \pm 0.70$ & $77.10 \pm 1.03$ \\
\hline & $\begin{array}{c}\text { Glimepiride group (2 } \\
\mathrm{mg} / \mathrm{kg})\end{array}$ & $82.62 \pm 0.13$ & $80.55 \pm 0.25$ & $79.10 \pm 0.50$ & $78.19 \pm 1.08$ \\
\hline \multirow{3}{*}{ 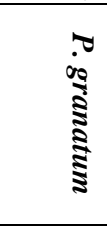 } & $\begin{array}{l}\text { MCE group (50 } \\
\mathrm{mg} / \mathrm{kg})\end{array}$ & $77.56 \pm 0.43$ & $76.33 \pm 1.89$ & $74.83 \pm 1.02$ & $76.16 \pm 1.10$ \\
\hline & $\begin{array}{l}\text { Ethyl acetate group } \\
(50 \mathrm{mg} / \mathrm{kg})\end{array}$ & $78.63 \pm 0.56$ & $76.16 \pm 1.01$ & $75.50 \pm 1.70$ & $78.40 \pm 1.23$ \\
\hline & $\begin{array}{l}\text { Aqueous group } \\
(50 \mathrm{mg} / \mathrm{kg})\end{array}$ & $79.50 \pm 0.60$ & $78.33 \pm 1.02$ & $75.50 \pm 1.20$ & $79.83 \pm 1.12$ \\
\hline \multirow{3}{*}{ 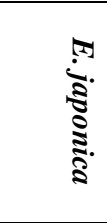 } & $\begin{array}{l}\text { MCE group (50 } \\
\mathrm{mg} / \mathrm{kg})\end{array}$ & $79.86 \pm 0.25$ & $78.37 \pm 1.79$ & $77.83 \pm 1.12$ & $81.26 \pm 1.20$ \\
\hline & $\begin{array}{l}\text { Chloroformic group } \\
(50 \mathrm{mg} / \mathrm{kg})\end{array}$ & $81.93 \pm 1.32$ & $80.16 \pm 1.66$ & $78.53 \pm 1.20$ & $82.10 \pm 1.73$ \\
\hline & $\begin{array}{l}\text { Aqueous group } \\
(50 \mathrm{mg} / \mathrm{kg})\end{array}$ & $79.40 \pm 0.75$ & $78.36 \pm 1.12$ & $81.30 \pm 1.10$ & $82.53 \pm 1.62$ \\
\hline \multirow{3}{*}{ 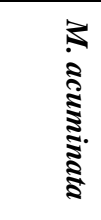 } & $\begin{array}{l}\text { MCE group (50 } \\
\mathrm{mg} / \mathrm{kg})\end{array}$ & $79.17 \pm 0.33$ & $77.63 \pm 1.79$ & $76.83 \pm 1.12$ & $82.16 \pm 1.10$ \\
\hline & $\begin{array}{l}\text { Ethyl acetate group } \\
(50 \mathrm{mg} / \mathrm{kg})\end{array}$ & $81.36 \pm 0.76$ & $80.26 \pm 1.11$ & $79.50 \pm 1.60$ & $83.50 \pm 1.33$ \\
\hline & $\begin{array}{l}\text { Aqueous group } \\
(50 \mathrm{mg} / \mathrm{kg})\end{array}$ & $80.40 \pm 0.75$ & $79.34 \pm 1.22$ & $80.50 \pm 1.20$ & $83.33 \pm 1.02$ \\
\hline
\end{tabular}

Mean $\pm \mathrm{SD}, \mathrm{n}=6$ in each group with compared with respective normal control.

Table 6. Hypo-glycemic action of methanolic leaves extracts of P. granatum, E. japonica, M. acuminata and their fractions on blood glucose level in OGTT in normal rats.

\begin{tabular}{|c|c|c|c|c|c|c|}
\hline Plants & Treatment & $0 \mathrm{~min}$ & $30 \mathrm{~min}$ & $60 \mathrm{~min}$ & $120 \mathrm{~min}$ & Mean \\
\hline \multirow{5}{*}{ 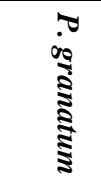 } & Control group & $81.62 \pm 0.491 \mathrm{~m}$ & $82.32 \pm 0.52 \mathrm{klm}$ & $85.53 \pm 0.46 \mathrm{jk}$ & $83.63 \pm 1.04 \mathrm{kl}$ & $83.27 \pm 0.44 \mathrm{E}$ \\
\hline & Glimepiride group $(2 \mathrm{mg} / \mathrm{kg})$ & $80.80 \pm 0.691 \mathrm{mn}$ & $132.04 \pm 0.83 \mathrm{~d}$ & $94.11 \pm 0.93 \mathrm{hi}$ & $88.54 \pm 0.85 \mathrm{j}$ & $98.87 \pm 4.13 \mathrm{D}$ \\
\hline & MCE group $(50 \mathrm{mg} / \mathrm{kg})$ & $79.51 \pm 0.66 \mathrm{mn}$ & $147.32 \pm 1.13 \mathrm{a}$ & $110.05 \pm 0.88 \mathrm{e}$ & $97.97 \pm 1.10 \mathrm{~g}$ & $108.71 \pm 5.19 \mathrm{~A}$ \\
\hline & Ethyl acetate group $(50 \mathrm{mg} / \mathrm{kg})$ & $80.73 \pm 0.621 \mathrm{mn}$ & $135.74 \pm 0.85 \mathrm{c}$ & $100.15 \pm 0.76 \mathrm{fg}$ & $92.59 \pm 0.95 \mathrm{i}$ & $102.30 \pm 4.29 \mathrm{C}$ \\
\hline & Aqueous group $(50 \mathrm{mg} / \mathrm{kg})$ & $77.31 \pm 0.47 \mathrm{n}$ & $140.13 \pm 0.99 \mathrm{~b}$ & $101.57 \pm 1.14 \mathrm{f}$ & $96.85 \pm 0.91 \mathrm{gh}$ & $103.96 \pm 4.77 \mathrm{~B}$ \\
\hline \multirow{5}{*}{ 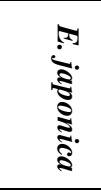 } & Control group & $81.62 \pm 0.491 \mathrm{mn}$ & $82.49 \pm 0.641 \mathrm{~m}$ & $85.53 \pm 0.46 \mathrm{k}$ & $83.63 \pm 1.04 \mathrm{kl}$ & $83.32 \pm 0.45 \mathrm{E}$ \\
\hline & Glimepiride group $(2 \mathrm{mg} / \mathrm{kg})$ & $80.80 \pm 0.691-\mathrm{o}$ & $132.04 \pm 0.83 \mathrm{~d}$ & $94.11 \pm 0.93 i$ & $88.54 \pm 0.85 \mathrm{j}$ & $98.87 \pm 4.13 \mathrm{D}$ \\
\hline & MCE group $(50 \mathrm{mg} / \mathrm{kg})$ & $78.87 \pm 0.67$ no & $153.36 \pm 1.03 \mathrm{a}$ & $113.70 \pm 0.88 \mathrm{e}$ & $101.47 \pm 0.96 \mathrm{gh}$ & $111.85 \pm 5.65 \mathrm{~A}$ \\
\hline & Chloroformic group $(50 \mathrm{mg} / \mathrm{kg})$ & $79.49 \pm 0.53 \mathrm{mno}$ & $137.58 \pm 0.85 \mathrm{c}$ & $103.39 \pm 0.78 \mathrm{~g}$ & $94.07 \pm 0.84 \mathrm{i}$ & $103.63 \pm 4.47 \mathrm{C}$ \\
\hline & Aqueous group $(50 \mathrm{mg} / \mathrm{kg})$ & $78.42 \pm 0.750$ & $142.13 \pm 1.11 \mathrm{~b}$ & $108.48 \pm 0.82 \mathrm{f}$ & $99.69 \pm 0.98 \mathrm{~h}$ & $107.18 \pm 4.80 \mathrm{~B}$ \\
\hline \multirow{5}{*}{ 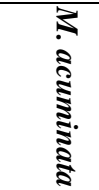 } & Control group & $81.62 \pm 0.491 \mathrm{~m}$ & $82.32 \pm 0.52 \mathrm{klm}$ & $85.53 \pm 0.46 \mathrm{jk}$ & $83.63 \pm 1.04 \mathrm{kl}$ & $83.27 \pm 0.44 \mathrm{E}$ \\
\hline & Glimepiride group $(2 \mathrm{mg} / \mathrm{kg})$ & $80.80 \pm 0.691 \mathrm{~m}$ & $132.04 \pm 0.83 \mathrm{~d}$ & $94.11 \pm 0.93 \mathrm{i}$ & $88.54 \pm 0.85 \mathrm{j}$ & $98.87 \pm 4.13 \mathrm{D}$ \\
\hline & MCE group $(50 \mathrm{mg} / \mathrm{kg})$ & $79.42 \pm 0.53 \mathrm{~m}$ & $158.32 \pm 0.74 \mathrm{a}$ & $119.20 \pm 0.86 \mathrm{e}$ & $111.40 \pm 0.96 \mathrm{f}$ & $117.08 \pm 5.87 \mathrm{~A}$ \\
\hline & Ethyl acetate group $(50 \mathrm{mg} / \mathrm{kg})$ & $80.14 \pm 0.751 \mathrm{~m}$ & $139.68 \pm 1.04 \mathrm{c}$ & $106.56 \pm 0.93 \mathrm{~g}$ & $97.34 \pm 0.94 \mathrm{i}$ & $105.93 \pm 4.54 \mathrm{C}$ \\
\hline & Aqueous group $(50 \mathrm{mg} / \mathrm{kg})$ & $78.75 \pm 0.91 \mathrm{~m}$ & $146.50 \pm 0.71 b$ & $113.37 \pm 0.93 \mathrm{f}$ & $102.35 \pm 0.89 \mathrm{~h}$ & $110.24 \pm 5.10 \mathrm{~B}$ \\
\hline
\end{tabular}

3.3.3. Effect of leaves extracts of $P$. granatum, E. japonica, and M. acuminata on diabetic rats after 28 days treatment.

Herbal products extracted from different naturally occurring plants can be used for the treatment of diabetic animals. In this study, natural products were applied to diabetic rats for 28 days as treatment. $P$. granatum, E. japonica, and M. acuminata leaves extracts were used for the diabetic rat's treatment. These products influence the pancreatic cells and promote the secretion of insulin to control blood sugar levels in animals. In the present study, Streptozotocin (naturally occurring nitrosourea alkylating reagent) was used as an inducer of diabetes, which attacks $\beta$-cells permanently and causes necrosis within 48-72 $\mathrm{h}$.

The herbal medicinal activity of repeated oral doses of $P$. granatum, E. japonica, and $M$. acuminata leaves extracts and their fractions were checked during the $7^{\text {th }}, 14^{\text {th }}, 21$ stand $28^{\text {th }}$ days in experimental rats and compared with control and experimental groups. Results are 
presented in Table 7 and Fig. 2. Streptozocin-induced diabetic rats exhibit a major boost in the concentration of blood glucose. So, sugar levels in the blood increased from 240.84 to 304.83 on the $28^{\text {th }}$ day. After oral treatment with ethyl acetate portion of $P$. granatum $(50 \mathrm{mg} / \mathrm{kg})$ blood glucose decreased from 242.07 to $124.48 \mathrm{mg} / \mathrm{dL}$.

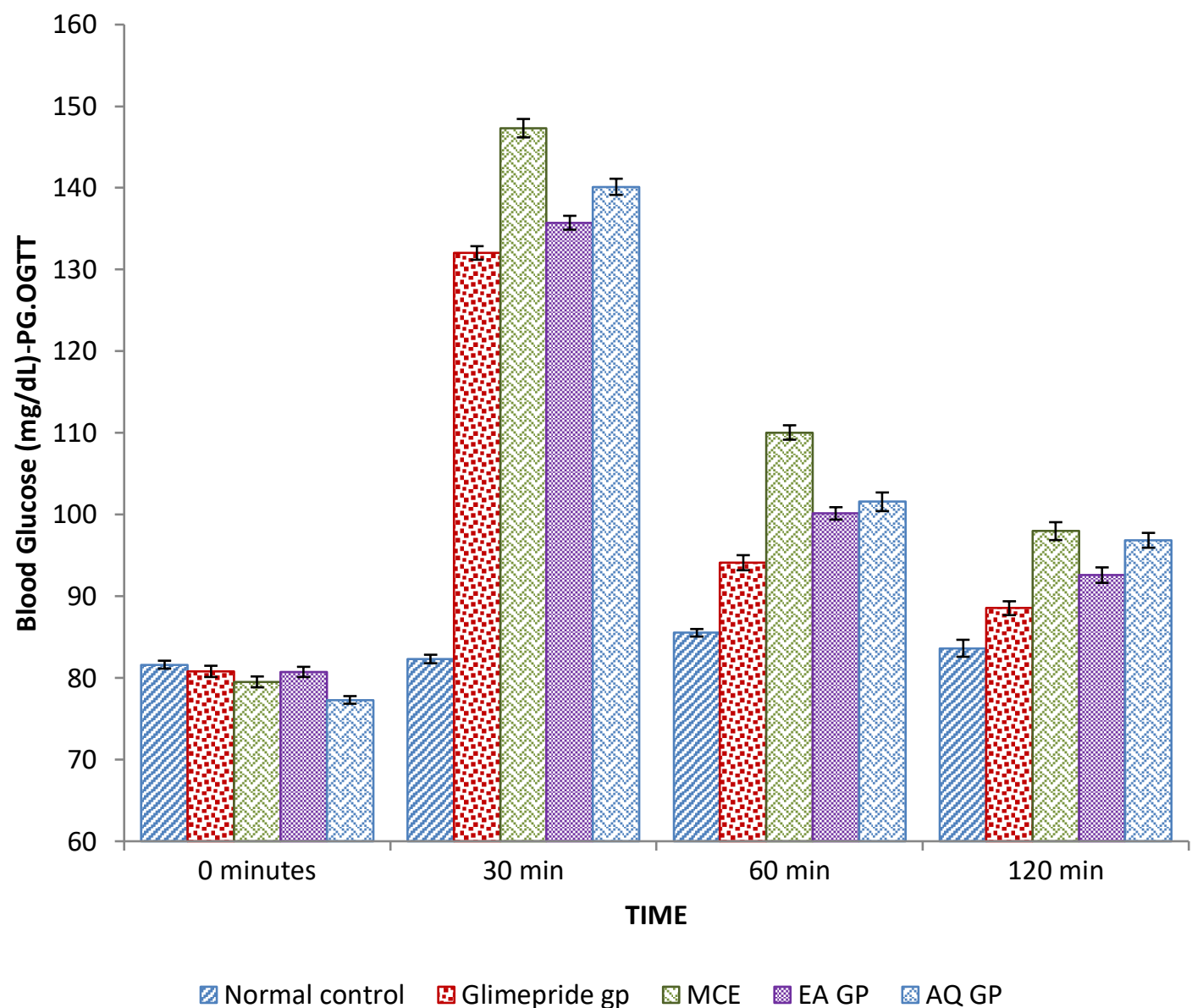

Figure 1. Representative graph of hypoglycemic action of methanolic crude extract of leaves of $P$. granatum and its fractions on blood sugar level in OGTT group rats.

After oral administration of chloroform fraction of E. japonica at the dose of $50 \mathrm{mg} / \mathrm{kg}$ the blood glucose was reduced when related to the control groups of diabetic rats. The decrease in sugar level was recorded from 246.37 to 127.96 . In contrast, treatment results with oral intake of ethyl acetate fraction of $M$. acuminata revealed that the $50 \mathrm{mg} / \mathrm{kg}$ dose decreases blood glucose level from 240.92 to 125.15 with a significant $\mathrm{p}$-value $(\mathrm{P}<0.005)$ [65].

3.4. Effect of P. granatum, E. japonica, and M. acuminata leaves extracts on in-vivo antioxidant parameters.

Enzymatic antioxidants play a crucial role in preventing cells from exposure to an oxidative type of harm. Sodium oxide dismutase (SOD) has got the ability to reduce the superoxide radical into hydrogen peroxide $\left(\mathrm{H}_{2} \mathrm{O}_{2}\right)$. Whereas catalase (CAT) reduces hydrogenperoxide and inhibits tissues in opposition to extremely reactive $\mathrm{OH}^{-1}$ radical. In $\mathrm{DM}$, the enhanced concentration of glucose can deactivate antioxidant activity like SOD and CAT by glycation of proteins, leading to lipid peroxidation (LPO).

In diabetic rats treated with leaves extracts of $P$. granatum, the level of liver SOD (6.44 to 5.87) and for CAT (82.68 to 71.24) showed maximum regain for ethyl acetate fraction treated group in contrast to the control group. As a result of regaining of SOD and CAT by the dose 
of ethyl acetate fraction of $P$. granatum a prominent reduction in LPO level was studied (0.505) in contrast to the control group (0.628) near to the corresponding normal control rats $(0.443)$.

Table 7. Hypo-glycemic action of methanolic leaves extracts of $P$. granatum, E. japonica, and M. acuminata and their fractions on blood glucose level in STZ induced diabetic rats after 28 days' treatment.

\begin{tabular}{|c|c|c|c|c|c|c|c|}
\hline \multirow{2}{*}{$\underset{\vec{\theta}}{\vec{\theta}}$} & \multirow[t]{2}{*}{ Treatment } & \multicolumn{5}{|c|}{ Blood Sugar Levels (mg/dL) } & \multirow[t]{2}{*}{ Mean } \\
\hline & & O Day & 7 Day & 14 Day & 21 Day & 28 Day & \\
\hline \multirow{6}{*}{ 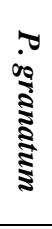 } & Control group & $81.21 \pm 0.68 \mathrm{~s}$ & $82.16 \pm 0.86 \mathrm{~s}$ & $81.56 \pm 0.97 \mathrm{~s}$ & $83.37 \pm 0.85 \mathrm{~s}$ & $79.90 \pm 1.09 \mathrm{~s}$ & $81.64 \pm 0.43 \mathrm{~F}$ \\
\hline & Diabetic control group (STZ, $40 \mathrm{mg} / \mathrm{kg}$ ) & $240.84 \pm 1.35 \mathrm{f}$ & $255.33 \pm 1.00 \mathrm{~d}$ & $271.67 \pm 1.30 \mathrm{c}$ & $290.81 \pm 1.73 b$ & $304.83 \pm 1.76 \mathrm{a}$ & $272.70 \pm 4.34 \mathrm{~A}$ \\
\hline & Glimepiride group $(2 \mathrm{mg} / \mathrm{kg})$ & $244.68 \pm 1.06 \mathrm{ef}$ & $189.22 \pm 1.17 \mathrm{j}$ & $158.76 \pm 0.89 \mathrm{mn}$ & $135.10 \pm 0.83 p$ & $110.71 \pm 1.00 \mathrm{r}$ & $167.69 \pm 8.63 \mathrm{E}$ \\
\hline & MCE group $(50 \mathrm{mg} / \mathrm{kg})$ & $246.98 \pm 1.24 \mathrm{e}$ & $214.16 \pm 1.02 \mathrm{~g}$ & $196.26 \pm 0.83 \mathrm{i}$ & $173.64 \pm 1.031$ & $146.56 \pm 0.93 \mathrm{o}$ & $195.52 \pm 6.38 \mathrm{~B}$ \\
\hline & Ethyl acetate group $(50 \mathrm{mg} / \mathrm{kg})$ & $242.07 \pm 1.11 \mathrm{ef}$ & $200.84 \pm 1.33 \mathrm{i}$ & $174.46 \pm 1.111$ & $155.76 \pm 1.21 \mathrm{n}$ & $124.48 \pm 1.01 \mathrm{q}$ & $179.52 \pm 7.44 \mathrm{D}$ \\
\hline & Aqueous group $(50 \mathrm{mg} / \mathrm{kg})$ & $245.76 \pm 1.39 \mathrm{ef}$ & $208.54 \pm 1.27 \mathrm{~h}$ & $181.59 \pm 1.53 \mathrm{k}$ & $162.32 \pm 1.23 \mathrm{~m}$ & $133.54 \pm 0.91 p$ & $186.35 \pm 7.17 \mathrm{C}$ \\
\hline \multirow{6}{*}{ 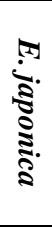 } & Control group & $81.21 \pm 0.68 \mathrm{~s}$ & $82.16 \pm 0.86 \mathrm{~s}$ & $81.56 \pm 0.97 \mathrm{~s}$ & $83.37 \pm 0.85 \mathrm{~s}$ & $79.90 \pm 1.09 \mathrm{~s}$ & $81.64 \pm 0.43 \mathrm{~F}$ \\
\hline & Diabetic control group (STZ, $40 \mathrm{mg} / \mathrm{kg}$ ) & $240.84 \pm 1.35 \mathrm{f}$ & $255.33 \pm 1.00 \mathrm{~d}$ & $271.67 \pm 1.30 \mathrm{c}$ & $290.81 \pm 1.73 b$ & $304.83 \pm 1.76 \mathrm{a}$ & $272.70 \pm 4.34 \mathrm{~A}$ \\
\hline & Glimepiride group $(2 \mathrm{mg} / \mathrm{kg})$ & $244.68 \pm 1.06 \mathrm{ef}$ & $189.22 \pm 1.17 \mathrm{k}$ & $158.76 \pm 0.89 n$ & $135.10 \pm 0.83 p$ & $110.71 \pm 1.00 \mathrm{r}$ & $167.69 \pm 8.63 \mathrm{E}$ \\
\hline & MCE group $(50 \mathrm{mg} / \mathrm{kg})$ & $243.32 \pm 1.30 \mathrm{ef}$ & $219.57 \pm 0.95 \mathrm{~g}$ & $197.21 \pm 0.87 \mathrm{j}$ & $171.81 \pm 1.291 \mathrm{~m}$ & $142.35 \pm 1.14 \mathrm{o}$ & $194.85 \pm 6.58 \mathrm{~B}$ \\
\hline & Chloroformic group $(50 \mathrm{mg} / \mathrm{kg})$ & $246.37 \pm 1.36 \mathrm{e}$ & $202.44 \pm 1.39 \mathrm{i}$ & $175.37 \pm 1.011$ & $157.19 \pm 0.96 n$ & $127.96 \pm 1.06 \mathrm{q}$ & $181.87 \pm 7.51 \mathrm{D}$ \\
\hline & Aqueous group $(50 \mathrm{mg} / \mathrm{kg})$ & $246.07 \pm 1.31 \mathrm{e}$ & $210.71 \pm 1.43 \mathrm{~h}$ & $186.61 \pm 0.93 \mathrm{k}$ & $168.88 \pm 1.03 \mathrm{~m}$ & $137.26 \pm 0.86 \mathrm{p}$ & $189.90 \pm 6.87 \mathrm{C}$ \\
\hline \multirow{6}{*}{ 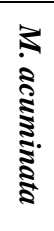 } & Control group & $81.21 \pm 0.68 \mathrm{r}$ & $82.16 \pm 0.86 \mathrm{r}$ & $81.56 \pm 0.97 \mathrm{r}$ & $83.37 \pm 0.85 \mathrm{r}$ & $79.90 \pm 1.09 \mathrm{r}$ & $81.64 \pm 0.43 \mathrm{~F}$ \\
\hline & Diabetic control group (STZ, $40 \mathrm{mg} / \mathrm{kg}$ ) & $240.84 \pm 1.35 \mathrm{f}$ & $255.33 \pm 1.00 \mathrm{~d}$ & $271.67 \pm 1.30 \mathrm{c}$ & $290.81 \pm 1.73 b$ & $304.83 \pm 1.76 \mathrm{a}$ & $272.70 \pm 4.34 \mathrm{~A}$ \\
\hline & Glimepiride group $(2 \mathrm{mg} / \mathrm{kg})$ & $244.68 \pm 1.06 \mathrm{ef}$ & $189.22 \pm 1.17 \mathrm{j}$ & $158.76 \pm 0.891$ & $135.10 \pm 0.83 \mathrm{o}$ & $110.71 \pm 1.00 \mathrm{~g}$ & $167.69 \pm 8.63 \mathrm{E}$ \\
\hline & MCE group $(50 \mathrm{mg} / \mathrm{kg})$ & $247.87 \pm 1.37 \mathrm{e}$ & $218.62 \pm 0.81 \mathrm{~g}$ & $198.94 \pm 1.32 \mathrm{i}$ & $174.70 \pm 0.87 \mathrm{k}$ & $145.60 \pm 0.85 n$ & $197.15 \pm 6.55 \mathrm{~B}$ \\
\hline & Ethyl acetate group $(50 \mathrm{mg} / \mathrm{kg})$ & $240.92 \pm 1.20 \mathrm{f}$ & $198.42 \pm 0.85 \mathrm{i}$ & $171.37 \pm 1.02 \mathrm{k}$ & $153.73 \pm 1.11 \mathrm{~m}$ & $125.15 \pm 0.85 p$ & $177.92 \pm 7.35 \mathrm{D}$ \\
\hline & Aqueous group $(50 \mathrm{mg} / \mathrm{kg})$ & $242.51 \pm 1.29 \mathrm{f}$ & $211.51 \pm 1.26 \mathrm{~h}$ & $187.16 \pm 0.89 \mathrm{j}$ & $171.61 \pm 1.01 \mathrm{k}$ & $136.05 \pm 0.910$ & $189.77 \pm 6.70 \mathrm{C}$ \\
\hline
\end{tabular}

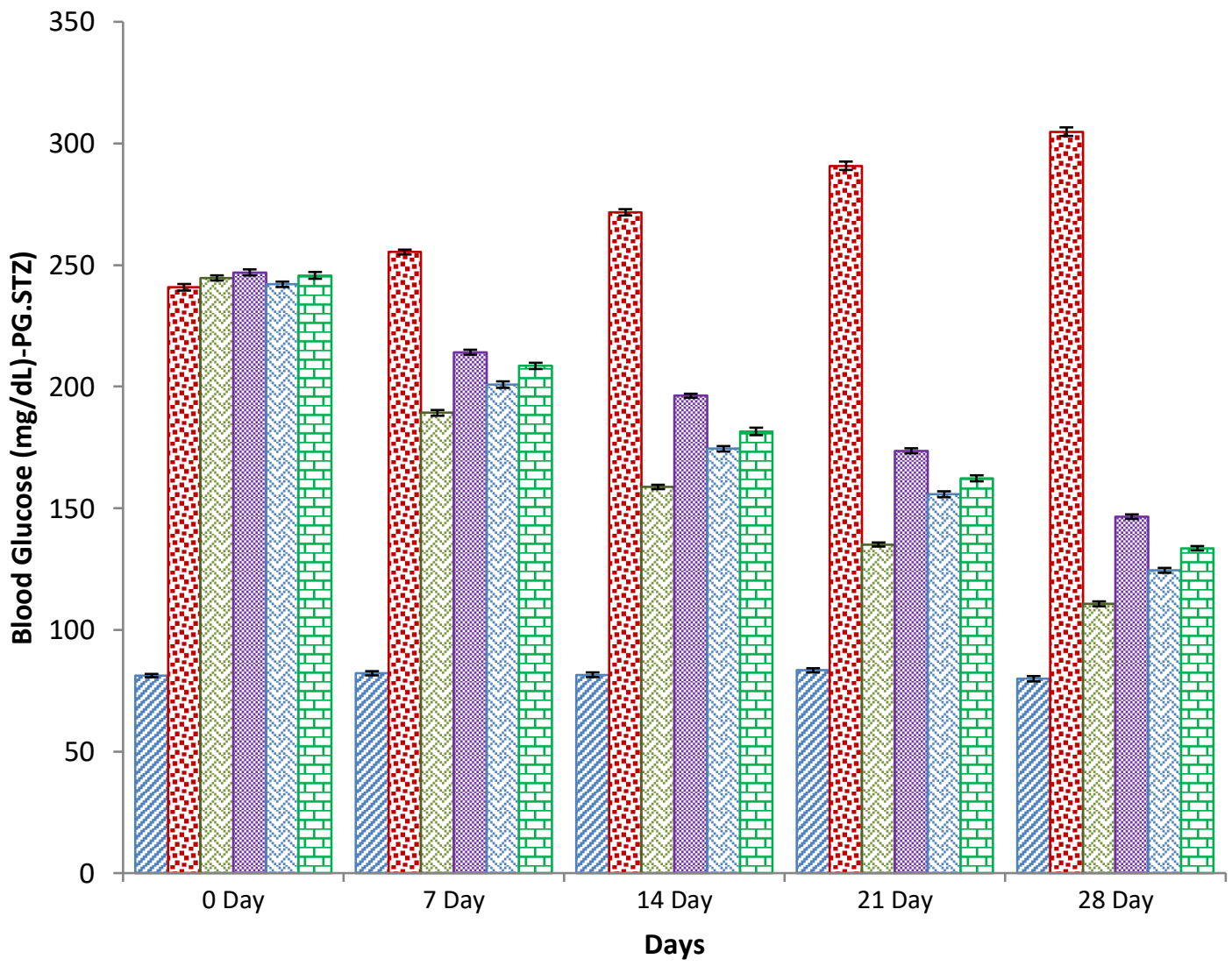

Normal control 国 Diabetic control Glimepride gp 图MCE

Figure 2. Representative graph of hypoglycemic action of methanolic crude extract of leaves of $P$. granatum and its fractions of on blood sugar level in STZ induced diabetic rats group.

For E. japonica leaves extract fractions, levels of liver SOD (6.44 to 6.11) and CAT (82.68 to 72.22) showed maximum regain for the chloroform fraction treated group in contrast to the control group. As a result of regaining SOD and CAT by treatment with chloroform 
fraction of E. japonica, a major decrease in LPO level was recorded (0.473) in contrast to the control group (0.623) near the corresponding normal control rats.

In rats treated with $M$. acuminata leaves extract fractions, the level of liver SOD (6.44 to 5.34) and CAT (82.68 \pm 0.05 to 68.27$)$ showed maximum regain for ethyl acetate fraction treated in contrast to the control group. As a result of regaining SOD and CAT by a dose of ethyl ethanoate fraction of M. acuminata a major decrease in LPO level was recorded (0.382) compared to diabetic control rats (0.623) near to the corresponding normal control rats.

After oral administration of leaves, extracts of $P$. granatum, E. japonica, and $M$. acuminata at the dose of $50 \mathrm{mg} / \mathrm{kg}$ and standard glimepiride tend to bring the values of SOD, CAT, and LPO back to normal and thereby help to control free radicals in the diabetic liver by activating the antioxidant defense system. The combined results are shown in Table 8 and Figures 3-5.

Table 8. The action of methanolic leaves extracts of plants under study and their fractions on activities of antioxidant enzyme in STZ induced diabetic rats.

\begin{tabular}{|c|c|c|c|c|c|}
\hline \multirow[t]{2}{*}{ Enzyme } & \multirow[t]{2}{*}{ Group } & \multicolumn{3}{|c|}{ Plants } & \multirow[t]{2}{*}{ Mean } \\
\hline & & P. granatum & E. japonica & M. acuminata & \\
\hline \multirow{6}{*}{ 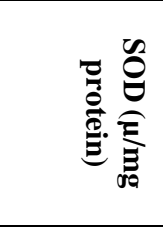 } & Normal control & $6.44 \pm 0.03 \mathrm{a}$ & $6.44 \pm 0.03 \mathrm{a}$ & $6.44 \pm 0.03 \mathrm{a}$ & $6.44 \pm 0.02 \mathrm{~A}$ \\
\hline & Diabetic control & $3.47 \pm 0.02 \mathrm{i}$ & $3.47 \pm 0.02 \mathrm{i}$ & $3.47 \pm 0.02 \mathrm{i}$ & $3.47 \pm 0.01 \mathrm{E}$ \\
\hline & Glimepiride & $6.39 \pm 0.03 \mathrm{a}$ & $6.39 \pm 0.03 \mathrm{a}$ & $6.39 \pm 0.03 \mathrm{a}$ & $6.39 \pm 0.01 \mathrm{~A}$ \\
\hline & Methanolic crude extract & $4.76 \pm 0.02 \mathrm{~h}$ & $5.24 \pm 0.02 \mathrm{ef}$ & $4.99 \pm 0.04 \mathrm{~g}$ & $5.00 \pm 0.05 \mathrm{D}$ \\
\hline & Ethyl acetate/Chloroform & $5.87 \pm 0.03 \mathrm{c}$ & $6.11 \pm 0.01 \mathrm{~b}$ & $5.34 \pm 0.16 \mathrm{e}$ & $5.77 \pm 0.09 \mathrm{~B}$ \\
\hline & Aqueous & $5.11 \pm 0.02 \mathrm{fg}$ & $5.55 \pm 0.03 \mathrm{~d}$ & $5.33 \pm 0.17 \mathrm{e}$ & $5.33 \pm 0.07 \mathrm{C}$ \\
\hline \multirow{6}{*}{ 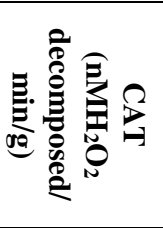 } & Normal control & $82.68 \pm 0.05 a$ & $82.68 \pm 0.05 \mathrm{a}$ & $82.68 \pm 0.05 a$ & $82.68 \pm 0.03 \mathrm{~A}$ \\
\hline & Diabetic control & $42.50 \pm 0.06 \mathrm{i}$ & $42.50 \pm 0.06 \mathrm{i}$ & $42.50 \pm 0.06 \mathrm{i}$ & $42.50 \pm 0.03 \mathrm{~F}$ \\
\hline & Glimepiride & $79.85 \pm 0.02 b$ & $79.85 \pm 0.02 b$ & $79.85 \pm 0.02 b$ & $79.85 \pm 0.01 \mathrm{~B}$ \\
\hline & Methanolic crude extract & $59.18 \pm 0.06 \mathrm{gh}$ & $59.57 \pm 0.37 \mathrm{~g}$ & $58.03 \pm 0.25 \mathrm{~h}$ & $58.93 \pm 0.21 \mathrm{E}$ \\
\hline & Ethyl acetate/Chloroform & $71.24 \pm 0.04 \mathrm{c}$ & $72.22 \pm 0.06 \mathrm{c}$ & $68.27 \pm 0.20 \mathrm{~d}$ & $70.57 \pm 0.41 \mathrm{C}$ \\
\hline & Aqueous & $64.47 \pm 0.04 \mathrm{e}$ & $68.45 \pm 0.06 \mathrm{~d}$ & $60.92 \pm 0.40 \mathrm{f}$ & $64.61 \pm 0.76 \mathrm{D}$ \\
\hline \multirow{6}{*}{ 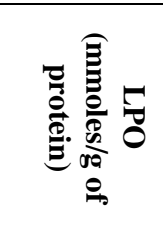 } & Normal control & $0.443 \pm 0.011 \mathrm{~g}$ & $0.443 \pm 0.011 \mathrm{~g}$ & $0.443 \pm 0.011 \mathrm{~g}$ & $0.443 \pm 0.006 \mathrm{C}$ \\
\hline & Diabetic control & $0.628 \pm 0.008 \mathrm{a}$ & $0.623 \pm 0.011 \mathrm{a}$ & $0.623 \pm 0.011 \mathrm{a}$ & $0.625 \pm 0.006 \mathrm{~A}$ \\
\hline & Glimepiride & $0.450 \pm 0.007 \mathrm{fg}$ & $0.440 \pm 0.011 \mathrm{~g}$ & $0.440 \pm 0.011 \mathrm{~g}$ & $0.443 \pm 0.005 \mathrm{C}$ \\
\hline & Methanolic crude extract & $0.547 \pm 0.008 \mathrm{~b}$ & $0.540 \pm 0.010 \mathrm{~b}$ & $0.467 \pm 0.017$ efg & $0.518 \pm 0.011 \mathrm{~B}$ \\
\hline & Ethyl acetate/Chloroform & $0.505 \pm 0.008 \mathrm{~cd}$ & $0.473 \pm 0.013 \mathrm{dg}$ & $0.382 \pm 0.019 \mathrm{~h}$ & $0.453 \pm 0.015 \mathrm{C}$ \\
\hline & Aqueous & $0.523 \pm 0.007 \mathrm{bc}$ & $0.497 \pm 0.011 \mathrm{cde}$ & $0.483 \pm 0.019 \mathrm{def}$ & $0.501 \pm 0.008 \mathrm{~B}$ \\
\hline
\end{tabular}

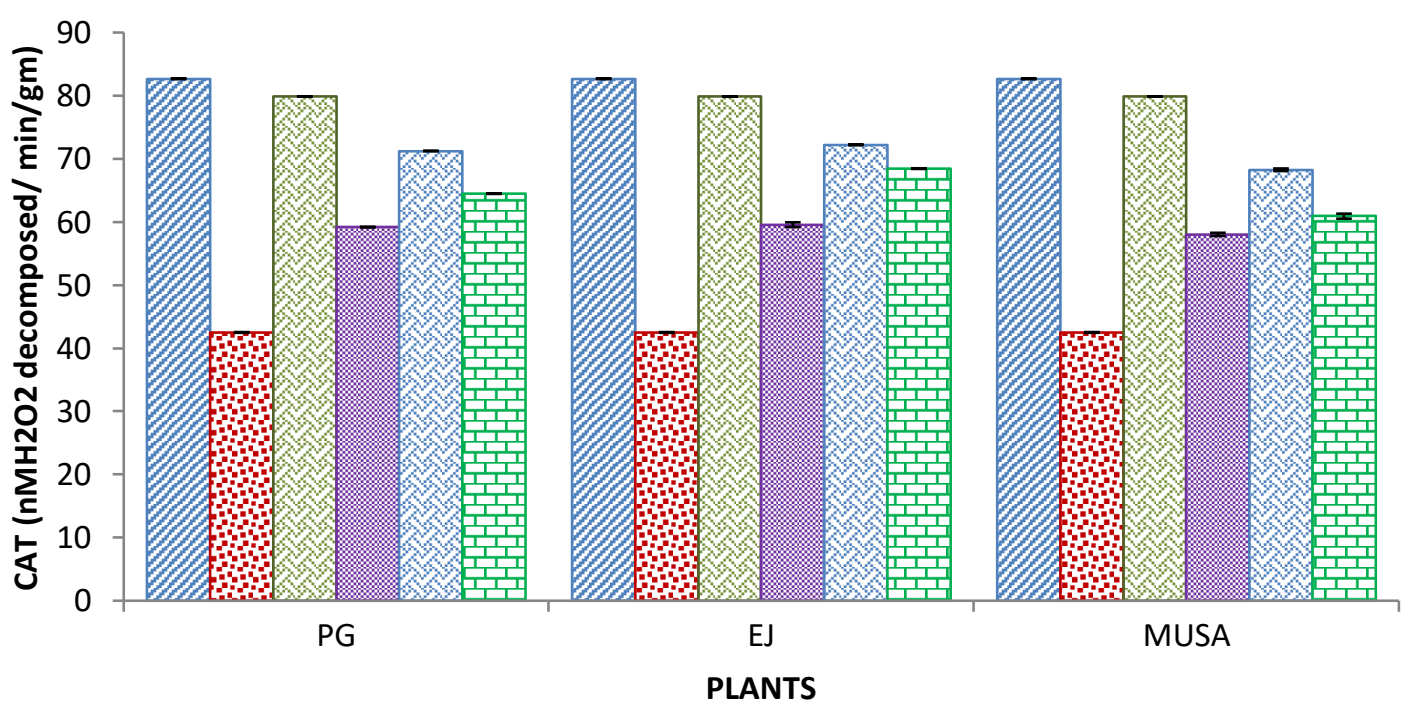
$\square$ Normal control
Diabetic control
잉 Glimepiride
Methanolic crude extract Ethyl acetate
$\boxplus$ Aqueous

Figure 3. Effect of methanolic crude extract of leaves of $P$. granatum (PG), E. japonica (EJ), and M. acuminata (Musa) and their fractions on activities of catalase (CAT) $\left(\mathrm{nMH}_{2} \mathrm{O}_{2}\right.$ decomposed $\left./ \mathrm{min} / \mathrm{g}\right)$ in STZ induced diabetic rats group. 


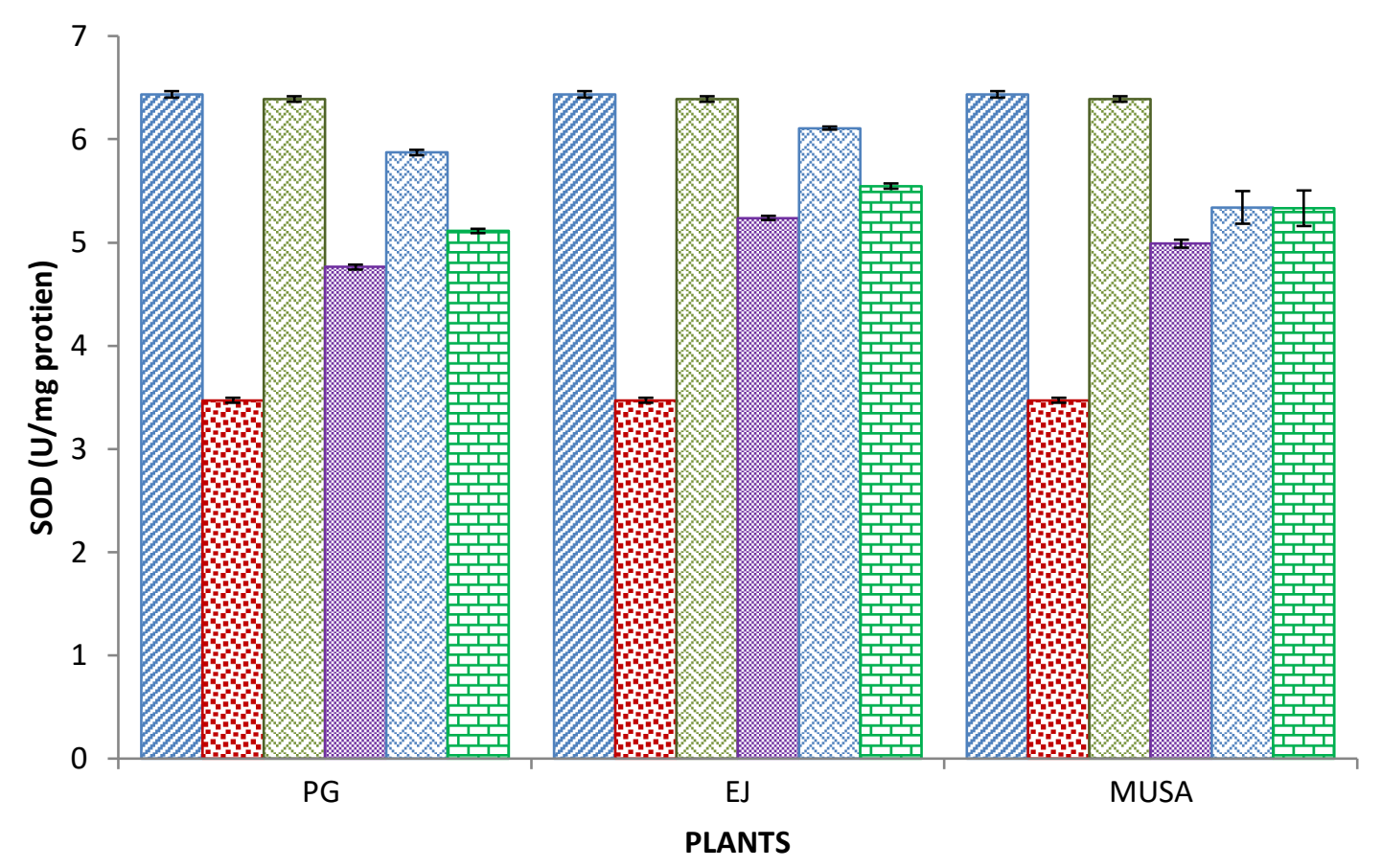
Normal control
Diabetic control
Glimepiride
Methanolic crude extract 娄 Ethyl acetate
$\boxplus$ Aqueous

Figure 4. Effect of methanolic crude extract of leaves of P. granatum (PG), E. japonica (EJ), and M. acuminata (Musa) and their fractions on activities of sodium oxide dismutase (SOD) ( $\mu / \mathrm{mg}$ protein) in STZ induced diabetic rats group.

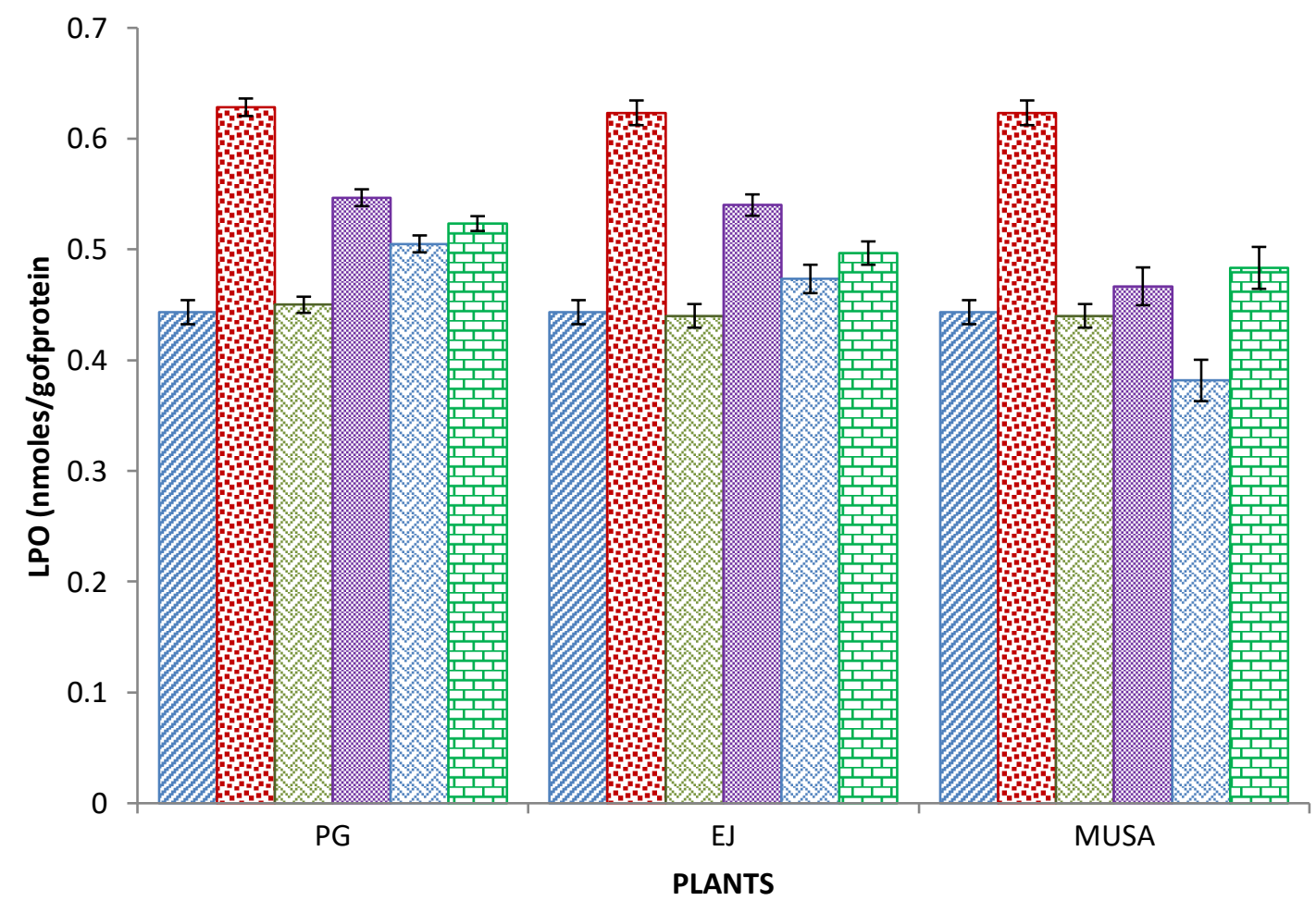
Normal control
因 Diabetic control
图 Glimepiride
Methanolic crude extract $\mathbf{0}$ Ethyl acetate
$\square$ Aqueous

Figure 5. Effect of methanolic crude extract of leaves of P. granatum (PG), E. japonica (EJ), and M. acuminata

(Musa)and their fractions on activities of LPO (nmoles/g of protein) in STZ induced diabetic rats group. 
3.5. Effect of $P$. granatum, E. japonica and M. acuminata leaves extracts and their fractions on body weight of different groups of rats.

Diabetes induced by streptozocin cause ruthless losses in weight of the organisms due to the breakdown of the structure of proteins or muscle destruction. The higher breakdown of protein for gluconeogenesis during insulin deficiency causes muscle wasting in diabetes. The body weight was slightly increased in the normal control rats from 157.31 to 185.10 (Table 9), whereas in the diabetic rats, there was a prominent decrease in body weight from 158.50 to 125.53, and the glimepiride treated group also showed an increase in body weight from 156.10 to 171.63 on 28 th day of study. After treatment with leaves extracts of $P$. granatum, rats showed an improvement in body weight which was maximum for ethyl acetate fed a group of rats from 160.50 to 166.33 , compared with diabetic control and standard glimepiride fed groups.

After oral treatment with leaves extracts of E. japonica, rats showed an enhancement in bodyweight which was maximum for the chloroform treated group of rats from 163 to 167, in contrast to the diabetic control and glimepiride groups. In rats fed the leaves extracts of M. acuminata orally, an improvement in body weight was recorded, which was maximum for ethyl acetate treated group of rats from 146.00 to 160.10, in contrast to the control group (diabetic) and glimepiride groups [66]. The potential of extracts to defend bodyweight decrease seems to be the effect of extract's capability to reduce hyperglycemia.

Table 9. The action of methanolic leaves extracts of P. granatum, E. japonica, and M. acuminata and their fractions on body weight of different groups of rats.

\begin{tabular}{|c|c|c|c|c|c|c|}
\hline \multirow[t]{2}{*}{ Treatment } & \multicolumn{6}{|c|}{ Effect of $P$. granatum on changes in body weight (g) } \\
\hline & 0 Day & $7^{\text {th }}$ Day & $14^{\text {th }}$ Day & $2^{\text {st }}$ Day & $28^{\text {th }}$ Day & Mean \\
\hline Control group & $157.31 \pm 4.15 \mathrm{e}$ & $162.50 \pm 4.1 \mathrm{~d}$ & $169.63 \pm 4.74 \mathrm{c}$ & $175.66 \pm 4.18 \mathrm{~b}$ & $185.10 \pm 3.15 \mathrm{a}$ & $170.04 \pm 4.06 \mathrm{~A}$ \\
\hline $\begin{array}{l}\text { Diabetic control } \\
\text { group (STZ, } 40 \\
\mathrm{mg} / \mathrm{kg})\end{array}$ & $158.50 \pm 6.52 \mathrm{e}$ & $147.53 \pm 4.08 \mathrm{i}$ & $143.36 \pm 8.19 \mathrm{~h}$ & $133.13 \pm 6.15 \mathrm{~g}$ & $125.53 \pm 1.78 \mathrm{f}$ & $141.61 \pm 5.34 \mathrm{~F}$ \\
\hline $\begin{array}{c}\text { Glimepiride } \\
\text { group }(2 \mathrm{mg} / \mathrm{kg})\end{array}$ & $156.10 \pm 5.17 \mathrm{e}$ & $152.15 \pm 6.14 j$ & $159.56 \pm 4.28 \mathrm{e}$ & $164.56 \pm 3.46 \mathrm{~d}$ & $171.63 \pm 3.16 \mathrm{c}$ & $160.8 \pm 4.43 \mathrm{~B}$ \\
\hline $\begin{array}{l}\text { MCE group (50 } \\
\mathrm{mg} / \mathrm{kg})\end{array}$ & $161.83 \pm 0.58 \mathrm{ef}$ & $150.50 \pm 2.74 \mathrm{j}$ & $152.00 \pm 3.34 \mathrm{j}$ & $159.50 \pm 4.20 \mathrm{e}$ & $160.00 \pm 4.96 \mathrm{~h}$ & $156.77 \pm 3.16 \mathrm{D}$ \\
\hline $\begin{array}{c}\text { Ethyl acetate } \\
\text { group }(50 \mathrm{mg} / \mathrm{kg})\end{array}$ & $160.50 \pm 2.50 \mathrm{efg}$ & $155.50 \pm 1.48 \mathrm{k}$ & $158.50 \pm 3.40 \mathrm{ef}$ & $161.83 \pm 4.75 \mathrm{~d}$ & $166.33 \pm 2.451$ & $160.53 \pm 2.92 \mathrm{C}$ \\
\hline $\begin{array}{l}\text { Aqueous group } \\
(50 \mathrm{mg} / \mathrm{kg})\end{array}$ & $157.10 \pm 1.05 \mathrm{e}$ & $152.33 \pm 4.18 \mathrm{j}$ & $154.66 \pm 3.18 \mathrm{j}$ & $157.53 \pm 1.51 \mathrm{ef}$ & $159.33 \pm 2.55 \mathrm{c}$ & $156.19 \pm 2.49 \mathrm{E}$ \\
\hline Mean & $158.56 \pm 3.33 \mathrm{C}$ & $153.42 \pm 3.29 \mathrm{E}$ & $156.29 \pm 4.52 \mathrm{D}$ & $158.70 \pm 4.04 \mathrm{~B}$ & $161.32 \pm 3.01 \mathrm{~A}$ & \\
\hline Treatment & \multicolumn{6}{|c|}{ Effect of $E$. japonica on changes in body weight $(\mathrm{g})$} \\
\hline Control group & $157.31 \pm 4.15 \mathrm{e}$ & $162.50 \pm 4.1 \mathrm{~d}$ & $169.63 \pm 4.74 \mathrm{c}$ & $175.66 \pm 4.18 \mathrm{~b}$ & $185.10 \pm 3.15 \mathrm{a}$ & $170.04 \pm 4.06 \mathrm{~A}$ \\
\hline $\begin{array}{c}\text { Diabetic control } \\
\text { group (STZ, } 40 \\
\mathrm{mg} / \mathrm{kg})\end{array}$ & $158.50 \pm 6.52 \mathrm{e}$ & $147.53 \pm 4.08 \mathrm{i}$ & $143.36 \pm 8.19 \mathrm{~h}$ & $133.13 \pm 6.15 \mathrm{~g}$ & $125.53 \pm 1.78 \mathrm{f}$ & $141.61 \pm 5.34 \mathrm{~F}$ \\
\hline $\begin{array}{c}\text { Glimepiride } \\
\text { group }(2 \mathrm{mg} / \mathrm{kg})\end{array}$ & $156.10 \pm 5.17 \mathrm{e}$ & $152.15 \pm 6.14 \mathrm{j}$ & $159.56 \pm 4.28 \mathrm{e}$ & $164.56 \pm 3.46 \mathrm{~d}$ & $171.63 \pm 3.16 \mathrm{c}$ & $160.8 \pm 4.43 \mathrm{C}$ \\
\hline $\begin{array}{l}\text { MCE group (50 } \\
\mathrm{mg} / \mathrm{kg})\end{array}$ & $160.83 \pm 0.78 \mathrm{e}$ & $153.50 \pm 2.14 \mathrm{j}$ & $149.50 \pm 3.74 \mathrm{i}$ & $152.50 \pm 3.20 \mathrm{j}$ & $154.57 \pm 4.36 \mathrm{j}$ & $154.18 \pm 2.84 \mathrm{E}$ \\
\hline $\begin{array}{c}\text { Ethyl acetate } \\
\text { group }(50 \mathrm{mg} / \mathrm{kg})\end{array}$ & $165.00 \pm 2.43 \mathrm{~m}$ & $161.33 \pm 2.84 \mathrm{efg}$ & $162.16 \pm 1.58 \mathrm{~d}$ & $164.50 \pm 1.12 \mathrm{~d}$ & $166.00 \pm 1.241$ & $163.80 \pm 1.84 \mathrm{~B}$ \\
\hline $\begin{array}{l}\text { Aqueous group } \\
(50 \mathrm{mg} / \mathrm{kg})\end{array}$ & $162.00 \pm 2.40 \mathrm{~d}$ & $155.43 \pm 3.80 \mathrm{ef}$ & $150.65 \pm 2.08 \mathrm{j}$ & $153.35 \pm 1.24 \mathrm{j}$ & $156.43 \pm 1.05 \mathrm{e}$ & $155.57 \pm 2.11 \mathrm{D}$ \\
\hline Mean & $159.96 \pm 3.57 \mathrm{~A}$ & $155.41 \pm 3.85 \mathrm{E}$ & $155.81 \pm 4.10 \mathrm{D}$ & $157.28 \pm 3.22 \mathrm{C}$ & $159.88 \pm 2.46 \mathrm{~B}$ & \\
\hline Treatment & \multicolumn{6}{|c|}{ Effect of $P$. granatum on changes in body weight (g) } \\
\hline Control group & $157.31 \pm 4.15 \mathrm{e}$ & $162.50 \pm 4.1 \mathrm{~d}$ & $169.63 \pm 4.74 \mathrm{c}$ & $175.66 \pm 4.18 \mathrm{~b}$ & $185.10 \pm 3.15 \mathrm{a}$ & $170.04 \pm 4.06 \mathrm{~A}$ \\
\hline $\begin{array}{c}\text { Diabetic control } \\
\text { group (STZ, } 40 \\
\mathrm{mg} / \mathrm{kg})\end{array}$ & $158.50 \pm 6.52 \mathrm{e}$ & $147.53 \pm 4.08 \mathrm{i}$ & $143.36 \pm 8.19 \mathrm{~h}$ & $133.13 \pm 6.15 \mathrm{~g}$ & $125.53 \pm 1.78 \mathrm{f}$ & $141.61 \pm 5.34 \mathrm{~F}$ \\
\hline $\begin{array}{c}\text { Glimepiride } \\
\text { group }(2 \mathrm{mg} / \mathrm{kg})\end{array}$ & $156.10 \pm 5.17 \mathrm{e}$ & $152.15 \pm 6.14 j$ & $159.56 \pm 4.28 \mathrm{e}$ & $164.56 \pm 3.46 \mathrm{~d}$ & $171.63 \pm 3.16 \mathrm{c}$ & $160.8 \pm 4.43 \mathrm{D}$ \\
\hline $\begin{array}{l}\text { MCE group (50 } \\
\mathrm{mg} / \mathrm{kg})\end{array}$ & $156.00 \pm 4.34 \mathrm{e}$ & $159.30 \pm 1.64 \mathrm{e}$ & $163.08 \pm 1.55 \mathrm{~d}$ & $167.30 \pm 4.02 \mathrm{c}$ & $170.10 \pm 0.04 \mathrm{c}$ & $163.16 \pm 2.32 \mathrm{C}$ \\
\hline https://b & terfaceresear & & & & & 36 \\
\hline
\end{tabular}




\begin{tabular}{c|c|c|c|c|c|c}
\multirow{2}{*}{ Treatment } & \multicolumn{7}{|c}{ Effect of P. granatum on changes in body weight $(\mathbf{g})$} \\
\cline { 2 - 7 } & $\mathbf{0 ~ D a y}$ & $\mathbf{7}^{\text {th }}$ Day & $\mathbf{1 4}^{\text {th }}$ Day & $\mathbf{2 1}^{\text {st }}$ Day & $\mathbf{2 8}^{\text {th }}$ Day & $\mathbf{M a a n}$ \\
\hline $\begin{array}{c}\text { Ethyl acetate } \\
\text { group }(50 \mathrm{mg} / \mathrm{kg})\end{array}$ & $152.33 \pm 0.88 \mathrm{e}$ & $157.10 \pm 1.11 \mathrm{e}$ & $162.77 \pm 2.44 \mathrm{~d}$ & $169.22 \pm 3.20 \mathrm{c}$ & $176.47 \pm 3.16 \mathrm{~b}$ & $163.58 \pm 2.16 \mathrm{~B}$ \\
\hline $\begin{array}{c}\text { Aqueous group } \\
(50 \mathrm{mg} / \mathrm{kg})\end{array}$ & $152.52 \pm 1.30 \mathrm{j}$ & $157.13 \pm 2.90 \mathrm{e}$ & $159.56 \pm 0.18 \mathrm{e}$ & $161.23 \pm 6.94 \mathrm{efg}$ & $164.34 \pm 4.15 \mathrm{efg}$ & $158.96 \pm 3.09 \mathrm{E}$ \\
\hline Mean & $155.46 \pm 3.73 \mathrm{E}$ & $155.95 \pm 3.33 \mathrm{D}$ & $159.66 \pm 3.56 \mathrm{C}$ & $161.85 \pm 4.66 \mathrm{~B}$ & $165.53 \pm 2.57 \mathrm{~A}$ &
\end{tabular}

Means showing similar letters among values in a column or a row, are statistically non-significant $(\mathrm{P}>0.05)$.

Small letters are to show the comparison among interaction means while capital letters are representing overall mean.

\subsection{Histopathology of rat pancreas.}

Examination of the cross-section of the pancreas of a normal, nondiabetic control rat showing normal anatomy of the islets of Langerhans, oval nuclei, and moderate cytoplasm. The pancreas of diabetic control rats exhibits the islets are in focal necrosis and mild inflammation, small nuclei, and moderate cytoplasm. Standard control (glimepiride $2 \mathrm{mg} / \mathrm{kg}$ ) rats have small oval nuclei and moderate cytoplasm without inflammation. A cross-sectional examination of the pancreas of diabetic rats treated with EAF (P. granatum) $(50 \mathrm{mg} / \mathrm{kg})$ showed that the islets of Langerhans are normal. Microscopic examination of the pancreas of diabetic rats treated with CFF (E. japonica) $(50 \mathrm{mg} / \mathrm{kg}$ ) exhibits no inflammation and oval nuclei with moderate cytoplasm. Pancreatic dissection of diabetic rats treated with EAF ( $M$. acuminata) $(50 \mathrm{mg} / \mathrm{kg}$ ) showed no inflammation and oval nuclei with moderate cytoplasm (Fig. 6). Histopathological studies on rats exhibit damaging of pancreatic $\beta$-cells in the diabetic control group, whereas in the glimepiride treated group and experimental group rats, there is regeneration in damaged $\beta$-cells.
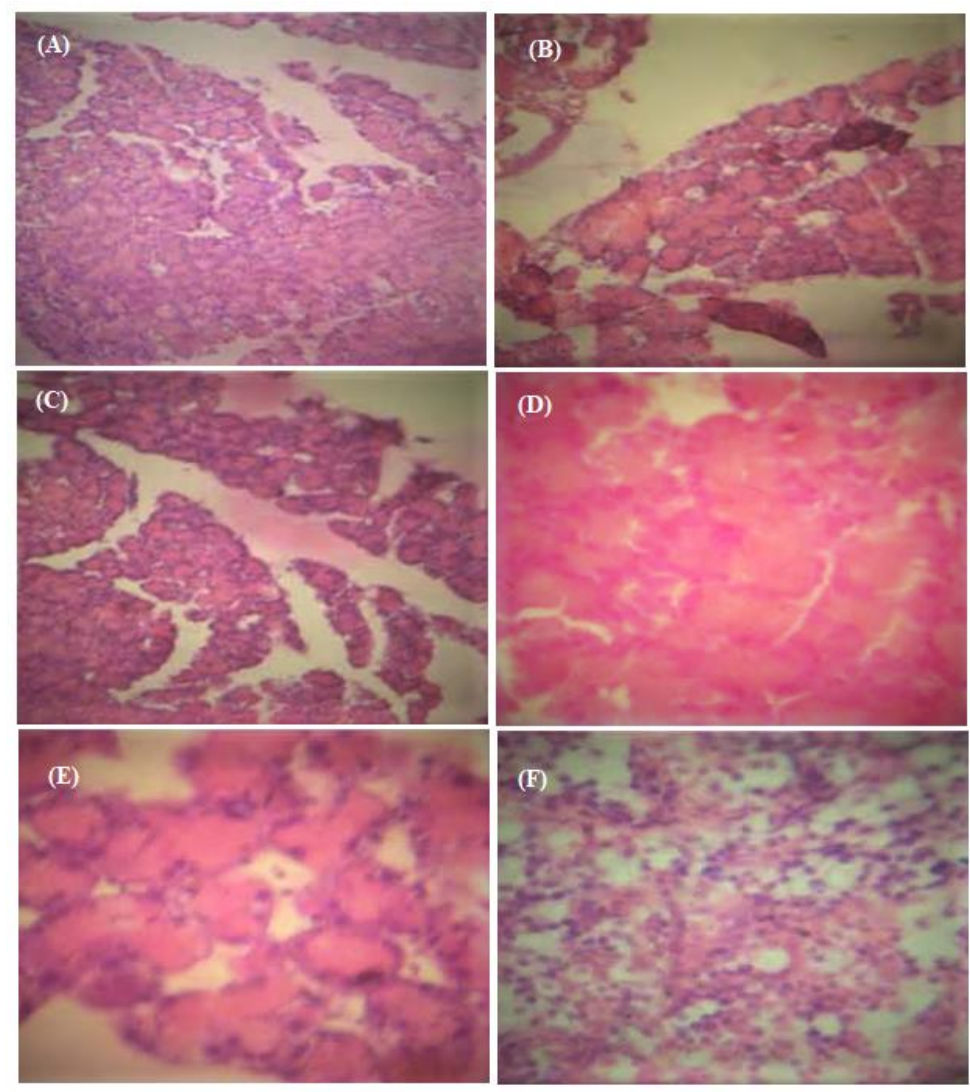

Figure 6. Histopathology of rat pancreas (A) normal non-diabetic control rat; (B) diabetic control rat; (C) standard diabetic control (glimepiride $2 \mathrm{mg} / \mathrm{kg}$ ); (D) diabetic rats treated with EAF (P. granatum) $(50 \mathrm{mg} / \mathrm{kg})$; (E) diabetic rats treated with CFF (E. japonica) $(50 \mathrm{mg} / \mathrm{kg}) ;($ F) diabetic rats treated with EAF (M. acuminata) $(50 \mathrm{mg} / \mathrm{kg})$. 


\section{Conclusions}

The present research confirms that the selected plant leaves extracts to possess potential antioxidant effects, which can also employ antidiabetic effects by regenerating the $\beta$-cells in STZ induced diabetic rats. The antioxidant and antidiabetic effects of selected plant leaf extracts can be attributed to different phytochemicals such as phenols, saponins, alkaloids, sterols, and flavonoids. From the results, we concluded that streptozocin (STZ) injection induces hyperglycemia and oxidative stress in normal rats. Administration of P. granatum, $E$. japonica, and $M$. acuminata extracts $(50 \mathrm{mg} / \mathrm{kg})$ to STZ induced diabetic rats reduces blood sugar level near to normal values and restores the body weight and oxidative defense 28 days of treatment. Thus, the plant leaves extracts to possess antidiabetic and antioxidant activity. Methanolic crude extracts of selected plant leaves and their fractions may have a promising effect locally where conventional treatment is not easily accessible to the general population due to the high cost.

\section{Funding}

This research received no external funding.

\section{Acknowledgments}

None.

\section{Conflicts of Interest}

The authors declare no conflict of interest.

\section{References}

1. Kamran, M.; Khan, M.R.; Khan, H.U.; Abbas, M.; Iqbal, M.; Nazir, A. Phytochemical and cytotoxic evaluation of Medicago monantha: In vivo protective potential in rats. Biomedicine \& Pharmacotherapy 2018, 102, 1052-1063.

2. Abbas, M.; Hussain, T.; Arshad, M.; Ansari, A.R.; Irshad, A.; Nisar, J.; Hussain, F.; Masood, N.; Nazir, A.; Iqbal, M. Wound healing potential of curcumin cross-linked chitosan/polyvinyl alcohol. International Journal of Biological Macromolecules 2019, 140, 871-876, https://doi.org/10.1016/j.ijbiomac.2019.08.153.

3. Alara, O.R.; Abdurahman, N.H.; Ukaegbu, C.I.; Azhari, N.H. Vernonia cinerea leaves as the source of phenolic compounds, antioxidants, and antidiabetic activity using microwave-assisted extraction technique. Industrial Crops and Products 2018, 122, 533-544, https://doi.org/10.1016/j.indcrop.2018.06.034.

4. Lu, J.; Fu, X.; Liu, T.; Zheng, Y.; Chen, J.; Luo, F. Phenolic composition, antioxidant, antibacterial and antiinflammatory activities of leaf and stem extracts from Cryptotaenia japonica Hassk. Industrial Crops and Products 2018, 122, 522-532, https://doi.org/10.1016/j.indcrop.2018.06.026.

5. Ghane, S.G.; Attar, U.A.; Yadav, P.B.; Lekhak, M.M. Antioxidant, antidiabetic, acetylcholinesterase inhibitory potential and estimation of alkaloids (lycorine and galanthamine) from Crinum species: An important source of anticancer and anti-Alzheimer drug. Industrial Crops and Products 2018, 125, 168-177, https://doi.org/10.1016/j.indcrop.2018.08.087.

6. Wongwad, E.; Pingyod, C.; Saesong, T.; Waranuch, N.; Wisuitiprot, W.; Sritularak, B.; Temkitthawon, P.; Ingkaninan, K. Assessment of the bioactive components, antioxidant, antiglycation and anti-inflammatory properties of Aquilaria crassna Pierre ex Lecomte leaves. Industrial Crops and Products 2019, 138, 111448, https://doi.org/10.1016/j.indcrop.2019.06.011.

7. Nazir, A.; Zahra, F.; Sabri, M.U.; Ghaffar, A.; Ather, A.Q.; Khan, M.I.; Iqbal, M. Charcoal Prepared from Bougainvillea spectabilis Leaves as Low Cost Adsorbent: Kinetic and Equilibrium Studies for Removal of Iron from Aqueous Solution. Zeitschrift für Physikalische Chemie 2021, 235, 265-279, https://doi.org/10.1515/zpch-2019-1455.

8. Arshad, M.; Rahman, A.; Qayyum, A.; Hussain, K.; Khan, M.A.; Hussain, T.; Abbas, M.; Shar, G.A.; Zahoor, M.K.; Nazir, A.; et al. Environmental Applications and Bio-Profiling of $\langle\mathrm{i}\rangle$ Tribulus Terrestris $\langle/ \mathrm{i}\rangle$ : an Ecofriendly Approach. Pol. J. Environ. Stud. 2020, 29, 2981-2986, https://doi.org/10.15244/pjoes/111240. 
9. Anjum, F.; Shahid, M.; Jilani, M.I.; Oranab, S.; Farooq, S.; Nazir, A.; Naz, S.; Iqbal, M. Evaluation of Antioxidant Potential and Cytotoxic Behavior of Different Varieties of <i>Allium sativum</i>. Pol. J. Environ. Stud. 2020, 29, 4447-4451, https://doi.org/10.15244/pjoes/116106.

10. Shaikh, S.H.; Malik, F.; James, H.; Abdul, H. Trends in the use of complementary and alternative medicine in Pakistan: a population-based survey. The Journal of Alternative and Complementary Medicine 2009, 15, 545-550.

11. Chen, Y.; Wang, E.; Wei, Z.; Zheng, Y.; Yan, R.; Ma, X. Phytochemical analysis, cellular antioxidant and $\alpha-$ glucosidase inhibitory activities of various herb plant organs. Industrial Crops and Products 2019, 141, 111771, https://doi.org/10.1016/j.indcrop.2019.111771.

12. Anwar, F.; Ali, M.; Hussain, A.I.; Shahid, M. Antioxidant and antimicrobial activities of essential oil and extracts of fennel (Foeniculum vulgare Mill.) seeds from Pakistan. Flavour and Fragrance Journal 2009, 24, 170-176.

13. Bashir, S.; Erum, A.; Kausar, R. Antimicrobial activity of some ethno-medicinal plants used in Pakistan. Research in Pharmacy 2012, 2, 42-45.

14. Ibrar, M.; Hussain, F.; Sultan, A. Ethnobotanical studies on plant resources of Ranyal hills, District Shangla, Pakistan. Pakistan Journal of Botany 2007, 39, 329-337.

15. Mahmood, A.; Mahmood, A.; Tabassum, A. Ethnomedicinal survey of plants from District Sialkot, Pakistan. J Appl Pharm 2011, 3, 212-220.

16. Lyra, R.; Oliveira, M.; Lins, D.; Cavalcanti, N. Prevenção do diabetes mellitus tipo 2. Arquivos Brasileiros de Endocrinologia \& Metabologia 2006, 50, 239-249.

17. Da Silva Xavier, G. The Cells of the Islets of Langerhans. J Clin Med 2018, 7, 54, https://doi.org/10.3390/jcm7030054.

18. Iqbal, D.N.; Shafiq, S.; Khan, S.M.; Ibrahim, S.M.; Abubshait, S.A.; Nazir, A.; Abbas, M.; Iqbal, M. Novel chitosan/guar gum/PVA hydrogel: Preparation, characterization and antimicrobial activity evaluation. International Journal of Biological Macromolecules 2020, 164, 499-509, https://doi.org/10.1016/j.ijbiomac.2020.07.139.

19. Iqbal, D.N.; Nazir, A.; Iqbal, M.; Yameen, M. Green synthesis and characterization of carboxymethyl guar gum: Application in textile printing technology. Green Processing and Synthesis 2020, 9, 212-218.

20. Iqbal, D.N.; Hussain, E.A.; Ghani, A.; Hassan, F.; Bukhari, A.; Iftikhar, S.; Nazir, A.; Ahmad, A.; Iqbal, M. Green and Environmentally Friendly Techniques for Enhanced Physicochemical Characteristics Attributed to Polysaccharides for Industrial Applications. Pol. J. Environ. Stud. 2020, 29, 3457-3466, https://doi.org/10.15244/pjoes/111511.

21. Chaudhry, H.; Nisar, N.; Mehmood, S.; Iqbal, M.; Nazir, A.; Yasir, M. Indian Mustard Brassica juncea efficiency for the accumulation, tolerance and translocation of zinc from metal contaminated soil. Biocatalysis and Agricultural Biotechnology 2020, 23, 101489, https://doi.org/10.1016/j.bcab.2019.101489.

22. Mann, E.; Bellin, M.D. Secretion of insulin in response to diet and hormones. Pancreapedia: The Exocrine Pancreas Knowledge Base 2016.

23. Rother, K.I. Diabetes treatment—bridging the divide. The New England journal of medicine 2007, 356, 14991501 .

24. de la Monte, S.M.; Wands, J.R. Review of insulin and insulin-like growth factor expression, signaling, and malfunction in the central nervous system: relevance to Alzheimer's disease. Journal of Alzheimer's Disease 2005, 7, 45-61.

25. Grover, J.; Yadav, S.; Vats, V. Medicinal plants of India with antidiabetic potential. Journal of ethnopharmacology 2002, 81, 81-100.

26. Saxena, A.; Vikram, N.K. Role of selected Indian plants in management of type 2 diabetes: a review. The Journal of Alternative \& Complementary Medicine 2004, 10, 369-378.

27. Mukherjee, P.K.; Maiti, K.; Mukherjee, K.; Houghton, P.J. Leads from Indian medicinal plants with hypoglycemic potentials. Journal of Ethnopharmacology 2006, 106, 1-28.

28. Dewanjee, S.; Das, A.K.; Sahu, R.; Gangopadhyay, M. Antidiabetic activity of Diospyros peregrina fruit: effect on hyperglycemia, hyperlipidemia and augmented oxidative stress in experimental type 2 diabetes. Food and chemical toxicology 2009, 47, 2679-2685.

29. Kamboj, V.P. Herbal medicine. Current science 2000, 78, 35-39.

30. Gomathi, V.; Palanisamy, P.; Jaykar, B. Preliminary phytochemical and in-vitro antioxidant activity of the whole plant of Acanthospermum Hispidum DC. Int J Med Pharm 2013, 1, 22-32.

31. Bergman, M.; Varshavsky, L.; Gottlieb, H.E.; Grossman, S. The antioxidant activity of aqueous spinach extract: chemical identification of active fractions. Phytochemistry 2001, 58, 143-152.

32. Yaqoob, N.; Munir, H.; Aslam, F.; Naseer, R.; Kamal, S.; Hussain, S.; Rashid, M.; Shujaat, S.; Nazir, A.; Iqbal, M. Antioxidant Potential and Phenolic Contents of Various Flaxseed Cultivars from Different AgroIndustrial Regions. Pol. J. Environ. Stud. 2021, 30, 4325-4330, https://doi.org/10.15244/pjoes/132795.

33. Nazir, A.; Kalim, I.; Imran, M.; Bilal, M.A.; Zahra, N.; Ahmad, A.; Iqbal, M.; Fazal, U.; Ehtisham-ul-Haque, S. Incidences and Bio-Detoxification of Aflatoxins in Rice and Cattle Feed Crops under Different AgroEcological Zones. Pol. J. Environ. Stud. 2021, 30, 1949-1954, https://doi.org/10.15244/pjoes/121050. 
34. Lage, A.C.P.; Orlando Ladeira, L.; Mosqueira, L.; Magalhães Paniago, R.; Oliveira Castilho, R.; Amorim, J.M.; Pessoa, E.S.; Nuncira, J.; Faraco, A.A.G. Synthesis and characterization of gold nanorods using the natural products resveratrol, gallic acid, and a purified fraction of Stryphnodendron obovatum by seedless method. Environmental Nanotechnology, Monitoring \& Management 2021, 16, 100473, https://doi.org/10.1016/j.enmm.2021.100473.

35. Elshafei, A.M.; Othman, A.M.; Elsayed, M.A.; Al-Balakocy, N.G.; Hassan, M.M. Green synthesis of silver nanoparticles using Aspergillus oryzae NRRL447 exogenous proteins: optimization via central composite design, characterization and biological applications. Environmental Nanotechnology, Monitoring \& Management 2021, 100553, https://doi.org/10.1016/j.enmm.2021.100553.

36. Din, M.u.; Ali, A.; Yasir, M.; Jilani, M.I.; Shoaib, S.; Latif, M.; Ahmad, A.; Naz, S.; Aslam, F.; Iqbal, M.; et al. Chemical Composition and in vitro Evaluation of Cytotoxicity, Antioxidant and Antimicrobial Activities of Essential Oil Extracted from Myristica Fragrans Houtt. Pol. J. Environ. Stud. 2021, 30, 1585-1590, https://doi.org/10.15244/pjoes/124738.

37. Tripathi, Y.B. Free radicals in ayurveda. Ancient science of life 1998, 17, 158.

38. Breimer, L.H. Molecular mechanisms of oxygen radical carcinogenesis and mutagenesis: the role of DNA base damage. Molecular carcinogenesis 1990, 3, 188-197.

39. Sharma, S.; Singh, L.; Singh, S. A review on medicinal plants having antioxidant potential. Indian Journal of Research in Pharmacy and Biotechnology 2013, 1, 404-409.

40. Sivanandham, V. Free radicals in health and diseases-a mini review. Pharmacol Onl 2011, 1, 1062-1077.

41. Nimse, S.B.; Pal, D. Free radicals, natural antioxidants, and their reaction mechanisms. Rsc Advances 2015 , 5, 27986-28006.

42. Wenying, Y. Concern about the present status of diabetes \& take positive action. The Indian journal of medical research 2010, 132, 475.

43. Harborne, A. Phytochemical methods a guide to modern techniques of plant analysis; springer science \& business media: 1998.

44. Trease, G.; Evans, W. Pharmacognsy. 11th edn. Brailliar Tiridel Can. 1989.

45. Bashir, A.; Ali, N.; Bashir, S.; Choudhary, M. Biological activities of aerial parts of Tylophora hirsuta Wall. African Journal of Biotechnology 2009, 8, 4627-4631.

46. Barku, V.; Opoku-Boahen, Y.; Owusu-Ansah, E.; Dayie, N.; Mensah, F. In-vitro assessment of antioxidant and antimicrobial activities of methanol extracts of six wound healing medicinal plants. In-Vitro 2013, 3, 7480.

47. Khan, A.S.; Arif, K.; Munir, B.; Kiran, S.; Jalal, F.; Qureshi, N.; Hassan, S.M.; Soomro, G.A.; Nazir, A.; Ghaffar, A.; et al. Estimating Total Phenolics in Taraxacum officinale (L.) Extracts. Pol. J. Environ. Stud. 2019, 28, 497-501, https://doi.org/10.15244/pjoes/78435.

48. Iqbal, M.; Iqbal, D.N.; Hussain, E.A.; Soomro, G.A.; Rizvi, H.; Nazir, A. Microwave-assisted green synthesis of guar gum esters with enhanced physicochemical properties. Scientia Iranica 2019, 26, 1474-1484.

49. Suleman, M.; Nouren, S.; Hassan, S.M.; Faiz, A.H.; Sahr, G.A.; Soomro, G.A.; Tahir, M.A.; Iqbal, M.; Nazir, A. Vitality and Implication of Natural Products from Viburnum Grandiflorum: an Eco-Friendly Approach. Pol. J. Environ. Stud. 2018, 27, 1407-1411, https://doi.org/10.15244/pjoes/76798.

50. Ashraf, R.; Sultana, B.; Riaz, S.; Mushtaq, M.; Iqbal, M.; Nazir, A.; Atif, M.; Zafar, Z. Fortification of phenolics, antioxidant activities and biochemical attributes of radish root by plant leaf extract seed priming. Biocatalysis and agricultural biotechnology 2018, 16, 115-120.

51. Qamar, A.; Asi, R.; Iqbal, M.; Nazir, A.; Arif, K. Survey of Residual Pesticides in Various Fresh Fruit Crops: A Case Study. Pol. J. Environ. Stud. 2017, 26, 2703-2709, https://doi.org/10.15244/pjoes/73801.

52. Ruch, R.J.; Cheng, S.-j.; Klaunig, J.E. Prevention of cytotoxicity and inhibition of intercellular communication by antioxidant catechins isolated from Chinese green tea. Carcinogenesis 1989, 10, 10031008.

53. Miller, G.L. Use of dinitrosalicylic acid reagent for determination of reducing sugar. Analytical chemistry 1959, 31, 426-428.

54. Zhang, P. Glucose tolerance test in mice. Bio-protocol Bio 2011, 101, e159.

55. Ali, M.Y.; Paul, S.; Tanvir, E.M.; Hossen, M.S.; Rumpa, N.-E.N.; Saha, M.; Bhoumik, N.C.; Aminul Islam, M.; Hossain, M.S.; Alam, N.; et al. Antihyperglycemic, Antidiabetic, and Antioxidant Effects of Garcinia pedunculata in Rats. Evidence-Based Complementary and Alternative Medicine 2017, 2017, 1-15, https://doi.org/10.1155/2017/2979760.

56. Okhawa, H.; Ohishi, N.; Yagi, K. Reaction of linoleic acid hydroperoxides with thiobarbituric acids. Anal Biochem 1979, 95, 351-354.

57. Kakkar, V.; Spindler, J.; Flute, P.; Corrigan, T.; Fossard, D.; Crellin, R.; Wessler, S.; Yin, E. Efficacy of low doses of heparin in prevention of deep-vein thrombosis after major surgery: a double-blind, randomised trial. The Lancet 1972, 300, 101-106.

58. Sinha, S.; Munichoodappa, C.S.; Kozak, G.P. Neuro-arthropathy (Charcot joints) in diabetes mellitus. Medicine 1972, 51, 191-210. 
59. Abbas, M.; Arshad, M.; Nisar, N.; Nisar, J.; Ghaffar, A.; Nazir, A.; Tahir, M.A.; Iqbal, M. Muscilage characterization, biochemical and enzymatic activities of laser irradiated Lagenaria siceraria seedlings. Journal of Photochemistry and Photobiology B: Biology 2017, 173, 344-352.

60. Jabeen, S.; Ali, S.; Nadeem, M.; Arif, K.; Qureshi, N.; Shar, G.A.; Soomro, G.A.; Iqbal, M.; Nazir, A.; Siddiqua, U.H. Statistical Modeling for the Extraction of Dye from Natural Source and Industrial Applications. Pol. J. Environ. Stud. 2019, 28, 2145-2150, https://doi.org/10.15244/pjoes/85125.

61. Arif, K.; Afzal, Z.; Nadeem, M.; Ahmad, B.; Mahmood, A.; Iqbal, M.; Nazir, A. Role of Graph Theory to Facilitate Landscape Connectivity: Subdivision of a Harary Graph. Pol. J. Environ. Stud. 2018, 27, 993-999, https://doi.org/10.15244/pjoes/75961.

62. Patil, R. N.; Patil, R. Y.; Ahirwar, B.; Ahirwar, D., Evaluation of antidiabetic and related actions of some Indian medicinal plants in diabetic rats. Asian Pacific Journal of Tropical Medicine 2011, 4 , 20-23

63. Calín-Sánchez, Á.; Figiel, A.; Hernández, F.; Melgarejo, P.; Lech, K.; Carbonell-Barrachina, Á.A. Chemical composition, antioxidant capacity, and sensory quality of pomegranate (Punica granatum L.) arils and rind as affected by drying method. Food and Bioprocess Technology 2013, 6, 1644-1654.

64. Boggula, N.; Peddapalli, H. Phytochemical analysis and evaluation of in vitro anti oxidant activity of Punica granatum leaves. International Journal of Pharmacognosy and Phytochemical Research 2017, 9, 1110-1118.

65. El-Hilaly, J.; Tahraoui, A.; Israili, Z.H.; Lyoussi, B. Acute hypoglycemic, hypocholesterolemic and hypotriglyceridemic effects of continuous intravenous infusion of a lyophilised aqueous extract of Ajuga iva L. Schreber whole plant in streptozotocin-induced diabetic rats. Pakistan journal of pharmaceutical sciences 2007, 20, 261-268.

66. Salman, M.; Shahid, M.; Sahar, T.; Naheed, S.; Arif, M.; Iqbal, M.; Nazir, A. Development of regression model for bacteriocin production from local isolate of Lactobacillus acidophilus MS1 using Box-Behnken design. Biocatalysis and Agricultural Biotechnology 2020, 24, 101542. 